Article

\title{
Financial Development and Economic Growth: The Role of Foreign-Owned Banks in CESEE Countries
}

\author{
Paola Bongini ${ }^{1}$, Małgorzata Iwanicz-Drozdowska ${ }^{2, *}$, Paweł Smaga ${ }^{2,3}$ and Bartosz Witkowski ${ }^{4}$ \\ 1 School of Economics and Statistics, Milan-Bicocca University, 20126 Milano, Italy; paola.bongini@unimib.it \\ 2 Institute of Finance, Warsaw School of Economics, 02-554 Warszawa, Poland \\ 3 National Bank of Poland, 00-919 Warszawa, Poland; psmaga@sgh.waw.pl \\ 4 Institute of Econometrics, Warsaw School of Economics, 02-554 Warszawa, Poland; bwitko@sgh.waw.pl \\ * Correspondence: miwani@sgh.waw.pl
}

Academic Editor: Yongrok Choi

Received: 28 December 2016; Accepted: 20 February 2017; Published: 3 March 2017

\begin{abstract}
This study focuses on the role of financial development in the economic growth of Central, Eastern and South-Eastern European (CESEE) countries in the post-communist era (1995-2014), which coincides with the opening up of financial markets to foreign investors and the global financial crisis. We investigate whether economic growth in CESEE countries has benefited from the presence of foreign-owned banks. To this end, we introduce some refined measures of financial development and control for banks' financial strength. Our results challenge the idea that bank credit fosters economic growth and that foreign-owned banks are indisputably a positive addition to local markets able to foster economic growth.
\end{abstract}

Keywords: financial development; economic growth; foreign-owned banks; post-communist economies

\section{Introduction}

This study focuses on the role of financial development in economic growth in Central, Eastern and South-Eastern European (CESEE) countries from the beginning of the post-communist era up to the period of the global financial crisis (GFC) and afterwards (1995-2014).

At the beginning of the economic and political transformations that took place in post-communist countries, there was a huge gap in the level of economic and financial development between this group of countries and advanced economies. However, the transformation period in post-communist countries has been marked by dynamic development. One of the key challenges has been the privatisation of state-owned banks and enterprises, as well as the liberalisation of market entry for private investors, both domestic and foreign. Foreign bank entry was especially high in the post-communist economies in the late 1990s and early 2000s, which contributed to the growth of nascent banking systems. According to [1], this partly reflected waves of reforms, including the opening up of Eastern Europe and other transition economies, as well as rapid financial globalisation before the GFC. This trend peaked in 2007 and slowed markedly after the outbreak of the crisis. The share of foreign-owned banks in banking sector assets in CESEE countries (see Table 1) ranges from $19 \%$ in Kosovo to $95 \%$ in Estonia. The stake of foreign-owned banks is below $50 \%$ in only five out of twenty countries (Kosovo, Ukraine, Belarus, Slovenia and Hungary). 
Table 1. Share of foreign banks in banking system assets in 2014.

\begin{tabular}{cccc}
\hline Albania $^{*}$ & $94 \%$ & Latvia & $53 \%$ \\
Belarus $^{*}$ & $30 \%$ & Lithuania & $92 \%$ \\
Bosnia and Herzegovina * & $86 \%$ & Moldova * & $72 \%$ \\
Bulgaria & $76 \%$ & Montenegro * & $89 \%$ \\
Croatia & $90 \%$ & Poland & $59 \%$ \\
Czech Republic & $91 \%$ & Romania & $90 \%$ \\
Estonia & $95 \%$ & Serbia & $74 \%$ \\
FYR Macedonia * & $66 \%$ & Slovakia & $84 \%$ \\
Hungary & $48 \%$ & Slovenia & $34 \%$ \\
Kosovo ${ }^{* *}$ & $19 \%$ & Ukraine & $28 \%$ \\
\hline
\end{tabular}

Note: * data for 2013; ** data for 2012. Source: Helgi Library, European Central Bank and national central bank data.

Given the importance of foreign ownership within the local banking system of CESEE countries, there is a need to investigate whether these countries have benefited, in terms of higher economic growth, from the presence and relevance of foreign-owned banks.

Our major contribution to the debate on finance and growth lies in identifying the role that foreign-owned banks play in fostering economic growth. Their role can be examined according to two main strands of literature, which interpret their presence either as: (i) an important source of innovation, competition and efficiency, with positive spill-over effects for the functioning of the banking system of the host country; or (ii) a source of credit contraction in the credit markets of host countries, for a variety of reasons, among which exposure to the financial troubles, either firm-specific or systematic, of their parent company is at present the most significant (see [1] for an extensive survey and updated analysis of the trends and worldwide impact of foreign banking). Accordingly, the impact of foreign-owned banks on the economic development of the host country is expected to be different. We trace the potential role of foreign-owned banks using two main measures: the decomposition of domestic credit to the private sector (as a ratio to GDP) according to the ownership structure of banks and the ratio of foreign-owned bank lending to total domestic credit.

The pioneering works by [2-4] triggered further analyses on the finance and growth nexus. The end of the twentieth and the beginning of the twenty-first century marked an increase in empirical and cross-country research on the implications of the development and structure of financial systems. In particular, the debate focused at first on the overall impact of the financial system and its depth on economic growth, causality and channels of influence, as well as the conditions necessary to achieve its positive relationship with GDP. The agenda then shifted to comparisons between bank- and market-based financial systems. The debate following the onset of the GFC has tended to employ a systemic perspective to analyse the fragility and limits of "oversized" financial systems in contributing to economic growth.

Notwithstanding these achievements, measures of financial development used in the literature are those traditionally proposed in the seminal works by $[5,6]$. However, the empirical literature on finance and growth tends to suffer from an insufficiently precise link between theory and measurement [7]. If theory focuses on particular functions provided by the financial sector-producing information, exerting corporate governance, facilitating risk management, pooling savings and easing exchange- and how these functions influence resource allocation decisions and economic growth, empirical works too frequently fail to directly measure these financial functions and employ the simple "size" of the financial system as a proxy for financial development. Our measurement strategy helps tackle this important issue. Our study seeks to contribute to this issue by proposing the decomposition of the "size" of the banking market, distinguishing between state-owned, privately owned and foreign-owned banks and banks owned by development banks. This can help to highlight whether the lending behaviour of banks of diverse types of ownership — and efficiency-fosters (or dampens) economic growth differently. Further, we complement our measure of bank development with a new 
measure of stock market development that underlines the role of financial markets in supporting non-financial companies, i.e., the true engine of the growth of an economy.

Our results cast doubt on the idea that bank credit fosters economic growth and that foreign-owned banks are a source of innovation, with positive spill-over effects in host banking markets. Conversely, we discover the channels through which financial development was conducive to higher growth in our sample of countries: on the one hand, the credit extended by banks owned by development banks, which was important in influencing the real economy; on the other hand, the development of stock markets, to the extent that these do not experience extremely volatile periods such as occurred at the start of 2008.

The paper is organised as follows. Section 2 reviews the relevant literature. Section 3 describes the model, the sample and the variables. Section 4 presents and discusses the empirical results, while Section 5 concludes the paper.

\section{Literature Review}

Many of the efforts of empirical research are devoted to delivering a final word, using sound and sophisticated econometric models, about the causal links between finance and growth, so as to address biases introduced by measurement error, reverse causation and problems relating to omitted variables [8]. The empirical literature is far from having reached a consensus, despite decades of evidence. Prominent qualitative surveys in the field include [7-9]. More recent surveys based on meta-analysis, which include [10,11], uncover the causes of the degree of heterogeneity in the empirical literature, such as the choice of financial variable proxies, the kind of data used (e.g., the number of countries or time periods under investigation) and the research design (e.g., addressing or ignoring the issue of endogeneity).

Although complete unanimity does not exist, the bulk of empirical research on the mechanisms through which finance affects growth suggests that [7]: (a) countries with better-functioning banks and markets grow faster; (b) simultaneity bias does not seem to drive these conclusions; and (c) better-functioning financial systems ease the external financing constraints that impede firm and industrial expansion.

In fact, a wealth of literature supports the positive and statistically significant, albeit non-linear, influence of a deepening financial system on economic growth. Besides theoretical modelling, most of the literature on growth and finance has focused on broad cross-section panels of countries with long-term data (for surveys, see $[7,12,13]$ ), showing that: (i) the finance and growth relationship differs among countries and depends on their level of economic development (e.g., the positive effect is most evident in low- to middle-income countries; see [14] for evidence for less developed countries); and (ii) financial sector deepening also reduces economic growth volatility. Granger causality seems to exist from financial development to economic growth and that the channels include improvements in resource allocation, accumulation of knowledge and productivity growth, rather than capital accumulation [9]. However, empirical studies unwittingly suffer from the drawback of choosing an appropriate, yet debatable, measure of financial development [15]. The strand of research linking finance to growth began with King and Levine, who used panel data for 80 countries during 1960-1989 and found that various measures of financial development levels were positively related to GDP per capita growth via productivity improvements $[5,16]$. In addition using vector error correction models, it was proved, for main industrialised economies, a long-run causality between measures of financial intensity and real per capita levels of output [17]. The positive relationship between the exogenous components of financial development and economic growth was also confirmed by [18] for a panel of 74 countries over the 1960-1995 period., In addition to banks, stock markets also were found to contribute to growth in long-run capital accumulation and productivity improvements [19]. Therefore, they should be analysed simultaneously. For a sample of 13 EU countries during 1976-2005, a long-run equilibrium relationship between the development of banking and stock markets and economic growth was found, but also a negative short-run effect between liquidity and economic development [20]. 
However, only a limited number of empirical studies tackle the growth and finance nexus in transition economies and sub-regions such as CESEE countries, in which this link is significantly weaker. For a data sample of 146 countries during 1975-2005 the finance-growth nexus shows a heterogeneous impact across regions, i.e., it is weaker for low-income countries [21]. In Middle East and North African countries, the banking sector makes a lower contribution to economic growth than in the rest of the world, while in Europe and Central Asia, the impact is greater. These differences are partly due to varied access to financial services and the degree of banking competition. The literature has focused on developed and high-income economies, as opposed to catch-up countries with younger and relatively less developed financial systems. The financial sectors in EU accession countries were found to share similar structures, characterised by a relatively low financial deepening level, underdeveloped stock markets, the dominant role of banks and a high degree of foreign presence [22]. In such an environment, a relatively weak contribution of the financial sector to economic growth is confirmed in South-Eastern Europe over 1993-2001, which may be due to the socialist legacy, as well as the failure to establish robustly and prudently functioning legal and regulatory frameworks [23]. This weak evidence of the link between financial development and economic growth in transition Central and Eastern European countries was also confirmed by [24], who argued that this is due to differences in fiscal and monetary discipline and the low enforcement capacity of governments that are excessively committed to bailout policies. A study using panel data from 25 transition countries during 1993-2000, supported the conclusion that the amount of bank credit to the private sector does not contribute to economic growth, as a result of soft budget constraints and banking crises in these economies [25]. The lack of a positive and significant relationship between financial development and economic growth in 13 CESEE countries in 1994-1999 was likewise proven by [26]. An overall weak relationship between bank development and growth in nine EU accession countries in 1996-2000 was found by [27] and no impact of stock market development on growth. Similarly, the weakness of the link for 16 CESEE countries during the 1991-2011 period was confirmed by [28], and was explained mainly by the high stock of NPL and banking crisis experiences. In the same vein, evidence by [29], focusing on 10 new European Union members in 1994-2007, suggested that the stock and credit markets in these economies are still underdeveloped and that their contribution to economic growth is limited, owing to low financial depth.

However, using longer panel data for 27 transition economies over the period 1989-2004, strong evidence to the contrary was provided by [30], namely that financial development has a positive and significant link to economic growth. This supports the previous assumption of [22] that proper financial development in a conducive environment may have just started in these economies. In a large set of countries for the period 1980-2009, including in Eastern Europe and Central Asia, no specific relationship was found between bank development, stock market development and economic growth [31]. The study concluded, that in order to achieve a long-run positive finance and growth relationship, as established by [19], those countries needed to increase domestic credit to the private sector and domestic savings to attract a higher level of investments. A recent study used a panel co-integration approach to analyse the role of financial deepening in economic growth over the period from 1970 to 2007 for 20 developed and 17 emerging countries in Africa, Asia and Latin America [32]. Unfortunately, CESEE countries were not included in the sample since the use of such a long time horizon is not possible for these countries. The study found that the impact of financial and trade openness differed for the two groups of countries. For developing countries, trade openness and financial deepening were more important than for developed ones. However, the time series did not cover the period of the global financial crisis.

Once economic and political transformations had begun, post-communist countries were treated by researchers either as a separate group of countries or as part of emerging markets. To date, foreign bank presence in CESEE countries has been analysed from four main points of view. First, researchers have analysed the market entrance of foreign banks (e.g., [33,34]). However, a new strand of research has since emerged, namely, the "exit" of foreign-owned banks from local markets. Second, there is 
a vast amount of research on the credit activity of CESEE banks (e.g., [35-39]). Third, there have been analyses on the performance of banks and the impact of foreign ownership (e.g., [40-44]. Fourth, market competition and the impact of foreign-owned banks have also been in focus (e.g., [45,46]).

This study combines two strands of empirical literature: one analysing the link between financial development and economic growth and the other focusing on the role of foreign banks in local markets. To the best of our knowledge, the first study combining the two strands by examining the effect of foreign banks on economic growth is [47]. However, their sample (1995-2003) covered only a few post-communist countries, with many other emerging markets and advanced economies. They concluded that, thanks to foreign-owned banks, external financing constraints had been relaxed and informational barriers and legal obstacles had diminished. Our study differs from [47] in the extended period of our analysis, which also covers the crisis and post-crisis years, as well as CESEE countries.

\section{Methodology and Data}

\subsection{Model and Variables}

Typically, the finance and growth relationship based on a panel of countries can schematically be presented $([7,48])$ as:

$$
\triangle G D P_{i t}=f\left(F_{i t}, C_{i t}, \varepsilon_{i t}\right)
$$

where $\Delta G D P_{i t}$ is the GDP growth of country $i$ in period $t ; F_{i t}$ represents the financial development indicators of country $i$ in period $t ; C_{i t}$ is the set of other independent variables of country $i$ in period $t$; and $\varepsilon_{i t}$ is the idiosyncratic error term. The dependent variable can be operationalised in different ways. In this paper, we model two types of GDP growth: total GDP and per capita GDP, both in constant prices.

The selection of the exact functional form of the model and the set of independent variables usually stems from the expanded Solow model. In particular, $C_{i t}$ includes variables representing certain measures of both physical and human capital. Furthermore, most of the empirical research confirms the existence of GDP beta convergence, which results in less developed countries catching up with more developed ones. The emanation of this is the inclusion of lagged GDP among the variables in $C_{i t}$, with the expectation of its negative impact on the growth rate. Finally, given the expected inequality of the steady states, which are the emanation of the ceteris paribus development level of different countries in an infinite time horizon, time-constant individual effects of particular countries are covered in $C_{i t} . F_{i t}$ includes explanatory variables of the level of financial development, which could be viewed as elements of physical capital presented separately for the purpose of emphasising their importance in the considered regressions.

The explanatory and dependent variables are listed and explained in Table 2. They can be divided into three main groups: macroeconomic, institutional and financial system development variables.

Table 2. Selected variables.

\begin{tabular}{llcc}
\hline \multicolumn{1}{c}{ Variables } & \multicolumn{1}{c}{ Definition } & $\begin{array}{c}\text { Expected Sign } \\
\text { for Economic } \\
\text { Development }\end{array}$ & Source of Data \\
\hline \multicolumn{1}{c}{ GDP growth } & Change in real GDP (year on year) & WB database \\
\hline $\begin{array}{l}\text { GDP per } \\
\text { capita growth }\end{array}$ & Change in real GDP per capita (year on year) & WB database \\
\hline \multicolumn{1}{c}{ Macroeconomic variables } & \\
\hline Inflation & Inflation annual data: average rate of change & WB database \\
\hline Government size & General government final consumption to GDP & - & WB database \\
\hline $\begin{array}{l}\text { Country's openness } \\
\text { to trade }\end{array}$ & (Exports + imports) to GDP & + & WB database \\
\hline
\end{tabular}


Table 2. Cont.

\begin{tabular}{|c|c|c|c|}
\hline Variables & Definition & $\begin{array}{l}\text { Expected Sign } \\
\text { for Economic } \\
\text { Development }\end{array}$ & Source of Data \\
\hline $\begin{array}{l}\text { Country's openness } \\
\text { to investments }\end{array}$ & FDI inflows to GDP & + & WB database \\
\hline \multicolumn{4}{|c|}{ Institutional characteristics } \\
\hline $\begin{array}{l}\text { Human capital } \\
\text { development }\end{array}$ & $\%$ of population ( $>15$ years) with tertiary education & + & $\begin{array}{l}\text { Barro and } \\
\text { Lee database }\end{array}$ \\
\hline Ruling party & $\begin{array}{l}4 \text { ruling party dummies that take value } 1 \text { when } \\
\text { respectively the left, right, centre-right or centre-left party } \\
\text { rules the country. Centre party is the reference category }\end{array}$ & \pm & $\begin{array}{l}\text { Parline and } \\
\text { hand-collected data }\end{array}$ \\
\hline Financial stability & $\begin{array}{l}\text { Financial strength index calculated considering the } \\
\text { country's banking system health }\end{array}$ & + & own \\
\hline \multicolumn{4}{|c|}{ Financial system development variables } \\
\hline \multirow{2}{*}{$\begin{array}{l}\text { Stock market } \\
\text { development }\end{array}$} & Stock market capitalisation to GDP & + & WB database \\
\hline & Stock market capitalisation of non-financial sector to GDP & + & Factset \\
\hline $\begin{array}{l}\text { Banking sector } \\
\text { development }\end{array}$ & Domestic credit to private sector to GDP & + & $\begin{array}{l}\text { Bankscope and } \\
\text { WB database }\end{array}$ \\
\hline \multirow[t]{2}{*}{$\begin{array}{l}\text { Foreign banks } \\
\text { relevance }\end{array}$} & $\begin{array}{l}\text { Domestic credit to private sector by bank ownership } \\
\text { (foreign-owned, state-owned, privately owned, owned by } \\
\text { development banks) to GDP }\end{array}$ & \pm & $\begin{array}{l}\text { Bankscope and } \\
\text { hand-collected data } \\
\text { on ownership } \\
\text { structure }\end{array}$ \\
\hline & $\begin{array}{l}\text { Share of the foreign-owned bank lending in domestic } \\
\text { credit to private sector }\end{array}$ & \pm & $\begin{array}{l}\text { Bankscope own } \\
\text { aggregation }\end{array}$ \\
\hline
\end{tabular}

\subsubsection{Measures of Macroeconomic Environments}

The first set includes variables typically used in growth models to analyse the impact of the macroeconomic context on economic growth (see, e.g., [49,50]). The empirical literature supports negative effects of inflation-a measure of monetary discipline-and government expenditure-a measure of government burden - on economic growth; instead, trade and investment openness are expected to be positively correlated with growth. On the one hand, by facilitating the exchange of goods and services, trade openness can foster economic growth (see, e.g., [32]); on the other hand, FDI inflows are expected to produce positive externalities in the form of technology transfer and spill-overs.

\subsubsection{Measures of Institutional Characteristics}

The second cluster includes variables highlighting the institutional characteristics of a country. Since [49] showed that an augmented Solow model, including the accumulation of human capital, improves the empirics of economic growth modelling, higher educational attainment among entire populations has been included in finance and growth models, with the expectation of positive effects on economic growth.

In addition to human capital development and to better qualify the institutional environment in our economies, we include two further variables.

The former delivers specific information about the ruling political party. Political parties tend to have different economic policies that are in turn aimed at influencing the country's economic growth and wealth distribution $([51,52])$. Therefore, we control for whether the country's ruling party was centre, centre-right, centre-left, right- or left-wing.

The second variable helps with qualifying the level of financial stability of the banking sector of our sample economies. Since the global financial crisis of 2008, it has been widely recognised that the financial system can exert its positive effects on economic growth to the extent that it does not excessively stack risks [9]. The growth benefits of financial sector deepening crucially depend on its stability. Problems typically arise when the financial system invests in financial innovations that 
aggressively increase its risk-taking appetite or reduce the effectiveness of the financial functions stressed in theoretical models of finance and growth. The recent financial crisis has stimulated an intertwined approach between research on the stability of financial intermediaries and the finance and growth literature. To the best of our knowledge, our paper is the first to include this dimension to qualify the role of the banking system in supporting economic development. The "financial strength index" (FSI) is defined as follows [53]:

$$
\begin{gathered}
\text { FSI }=0.2 \times \text { ETA }+0.2 \times \text { ROA }+ \\
+0.2 \times \text { Liquid_A_to_funding }-0.2 \times \text { Loans_to_Deposits } \\
-0.2 \times \text { L_impair_to_TA }
\end{gathered}
$$

where ETA is equity capital to total assets; ROA is the return on assets ratio; Liquid_A_to_Funding is the ratio of liquid assets to total funding; Loans_to_Deposits is the ratio of loans to customers to deposits from customers; and L_impair_to_TA is the ratio of impairment charges to total assets.

FSI is calculated on the bank level and then aggregated to the country level. It is a synthetic measure of the conditions under which a bank (a banking system) is viable and well run-profitable, liquid, well capitalised and not suffocated by an excessive burden of impaired loans. It resembles the CAMELS approach, except for management $(\mathrm{M})$ and sensitivity to market risk (S). The higher the value of the index, the more stable is the banking system. We expect a positive impact of FSI on economic development.

\subsubsection{Measures of Financial Development}

As proxies for financial system development, we first consider the two traditional ratios of credit to the private sector to GDP [5] and stock market capitalisation to GDP [6,19]. In addition, we specify the ratio of market capitalisation to GDP, considering only non-financial firms, in order to investigate the role of the stock market in easing capital-raising for those enterprises that represent the true engine of growth of an economy.

Finally, we include two measures controlling for the role of foreign-owned banks within the local financial system: the decomposition of domestic credit to the private sector (as a ratio to GDP) according to the ownership structure of banks and the ratio of foreign-owned banks' lending to total domestic credit.

The first variable captures the different roles played by state-owned, domestic privately owned and foreign-owned banks and banks owned by development banks (such as, e.g., EBRD)—called development banks in regressions. Ownership is usually considered as a proxy for bank efficiency, state-owned banks being considered the least efficient and foreign-owned the most efficient in the market. Since the efficiency of the banking system is the main channel through which the financial system can exert and play its role as a driver of economic growth, we believe that our measure can help to disentangle the contribution of different types of banks in fostering economic development.

The second variable captures the actual capability of foreign banks to impact the local financial system. Foreign banks can play a leading role-which does not necessarily translate into a positive judgement of their behaviour-to the extent that they hold an important share in the local credit market [54,55].

We challenge the role of foreign banks according to two main strands of literature at opposite ends of the spectrum with regard to the effect of the presence of foreign banks in a local banking market.

According to one view, foreign banks promote competition and efficiency in the host country, bring positive spill-over effects from best risk management and governance practices and introduce product and service innovations [37,40,56-60]. To the extent that these innovations can alleviate credit-market inefficiencies, relax external financing constraints on firm activities and stimulate industrial growth, foreign lending can significantly improve growth prospects in host countries [47]. In this sense, foreign banks can be considered a channel through which financial innovation is introduced within the economic system and, in consideration of the importance of innovation in 
the financial system in achieving its task as the engine of economic growth [61], we expect a positive and statistically significant sign of the coefficient of the estimate.

The opposing view is that foreign banks are a potential source of problems in the credit markets of host countries, for various reasons. First, their practice of "cherry picking" the best borrowers tends to worsen the remaining credit pool left to local banks, with less credit being extended to small and opaque borrowers [62-65]. Second, foreign banks may supply loans in foreign currencies, with detrimental effects on the financial stability of the host country if borrowers do not hedge this currency risk [66], as in the case of the East Asian Tigers in 1997-1999. Third, lending by foreign subsidiaries is negatively exposed to shocks to parent banks, either firm-specific or systematic [67-73]. In particular, the recent global financial crisis has challenged the idea that multinational banks play a positive role as shock absorbers in local markets; with reference to emerging European countries foreign subsidiaries were found to cut lending more than domestic banks and that this effect was more pronounced when the parent bank was financially weak $[38,70,73]$.

\subsection{Data and Methodology}

In order to describe the development path followed by CESEE countries, we present the evolution of their GDP and GDP per capita, the depth of each country's financial system and the relative importance of foreign banks in local markets, all in comparison to advanced economies (Figures 1-4). Although our sample period spans between 1995 and 2014, we provide statistics in Figures 1-3 only for the 1997-2014 period. This is because the applied estimation technique (system GMM estimator) requires the data from the first two waves of the considered panel data set to be used as instruments. As a result, the GDP variable efficiently used in the further discussed regressions is used as of 1997, while its earlier values are applied only in the role of instruments. It thus seems reasonable to limit its observation to the effectively used data. A similar issue refers to descriptive statistics, discussed in a later part of this section.

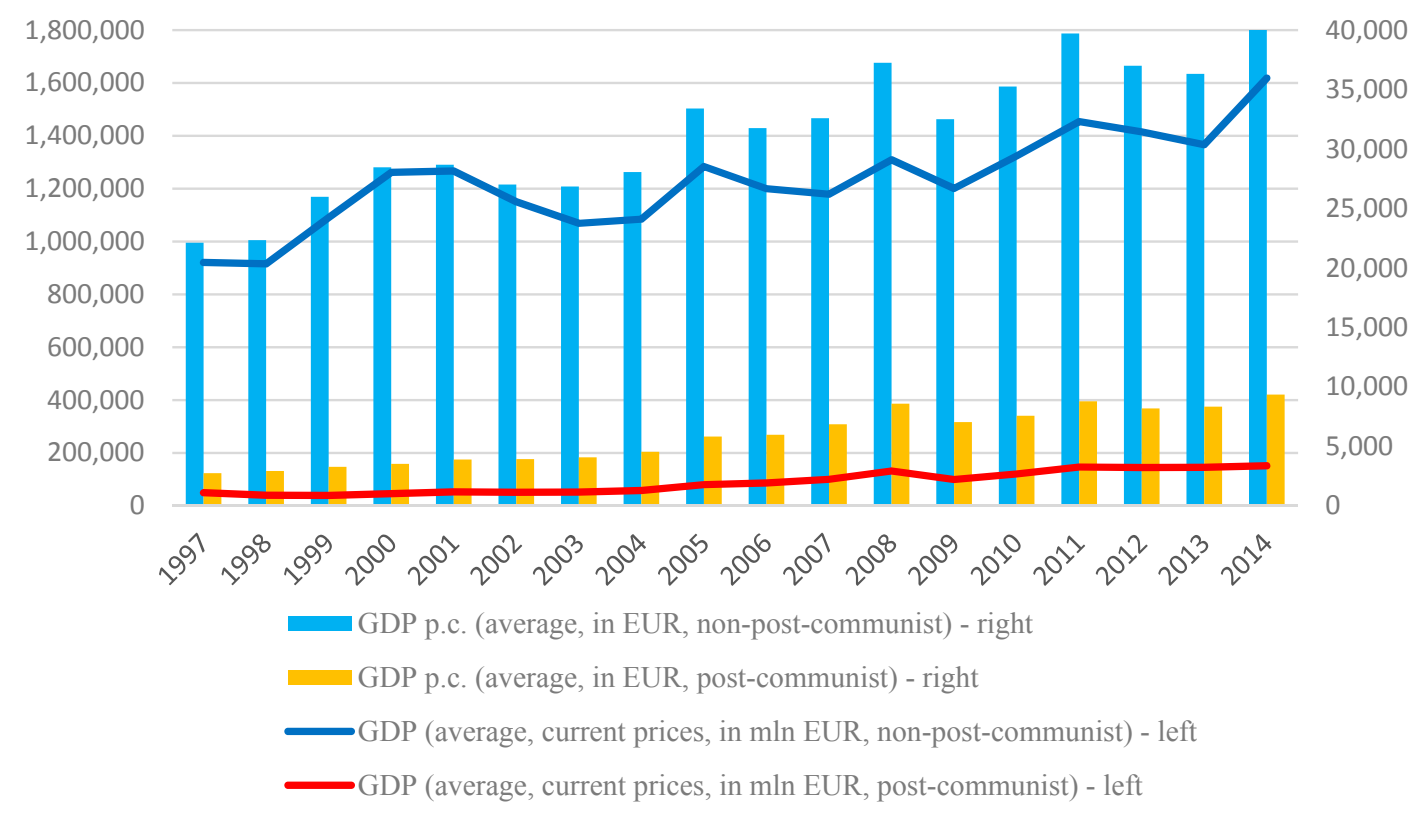

Figure 1. GDP and GDP per capita (1997-2014). Note: Arithmetic averages in both groups; based on ECB, World Bank, Helgi Library and national central banks' data.

It can be observed that differences between the two groups of countries still remain; however, post-communist countries have developed significantly. GDP per capita more than doubled between 1997 and 2014; the ratio of assets of monetary financial institutions (MFI) to GDP now exceeds, 
on average, $100 \%$, while the market share of foreign banks more than doubled from $30 \%$ of total banking assets in 1997 to more than 70\% in 2014. Stock market capitalisation to GDP, however small when compared to advanced economies, increased steadily and significantly until 2007. Nevertheless, the global financial crisis had a significant impact on this ratio, which retrenched to almost its 1997 value. Finally, Figure 4 graphically confirms the positive relationship between the measures of economic development and the depth of the financial system.

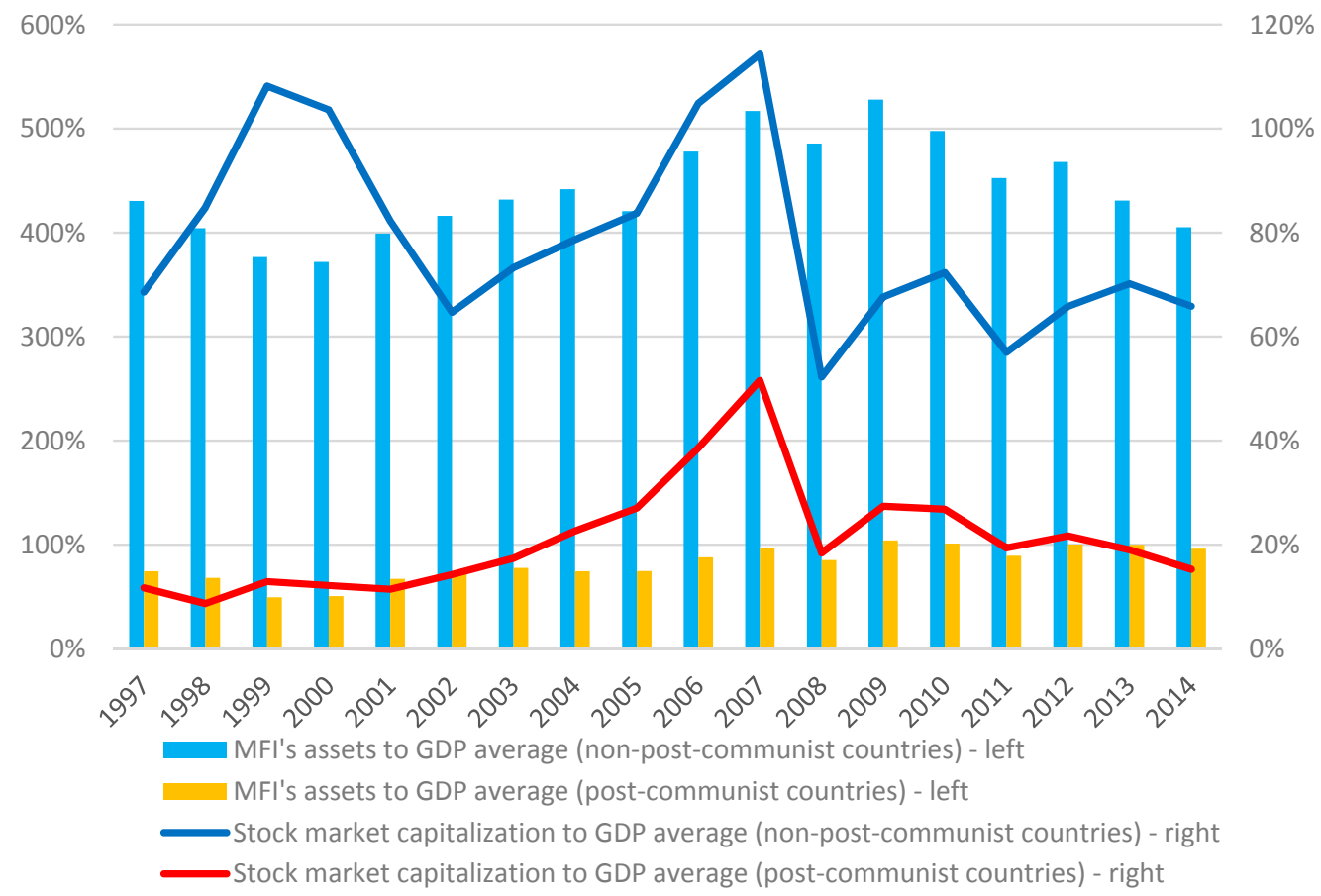

Figure 2. MFI assets to GDP and stock market capitalisation (1997-2014). Note: Arithmetic averages in both groups; based on the ECB, World Bank, Helgi Library and national central banks' data.

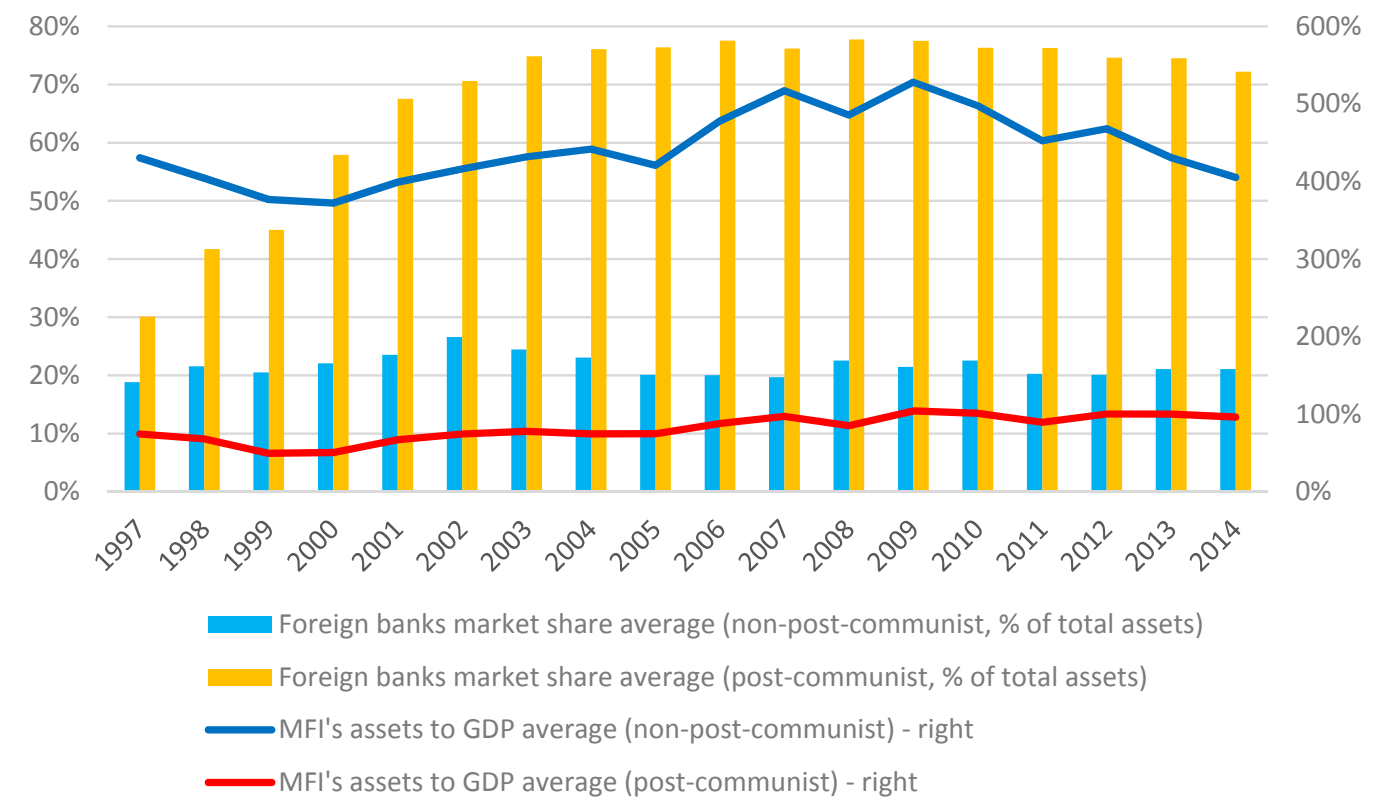

Figure 3. Foreign banks' market share (1997-2014). Note: Arithmetic averages in both groups; based on the ECB, World Bank, Helgi Library and national central banks' data. 


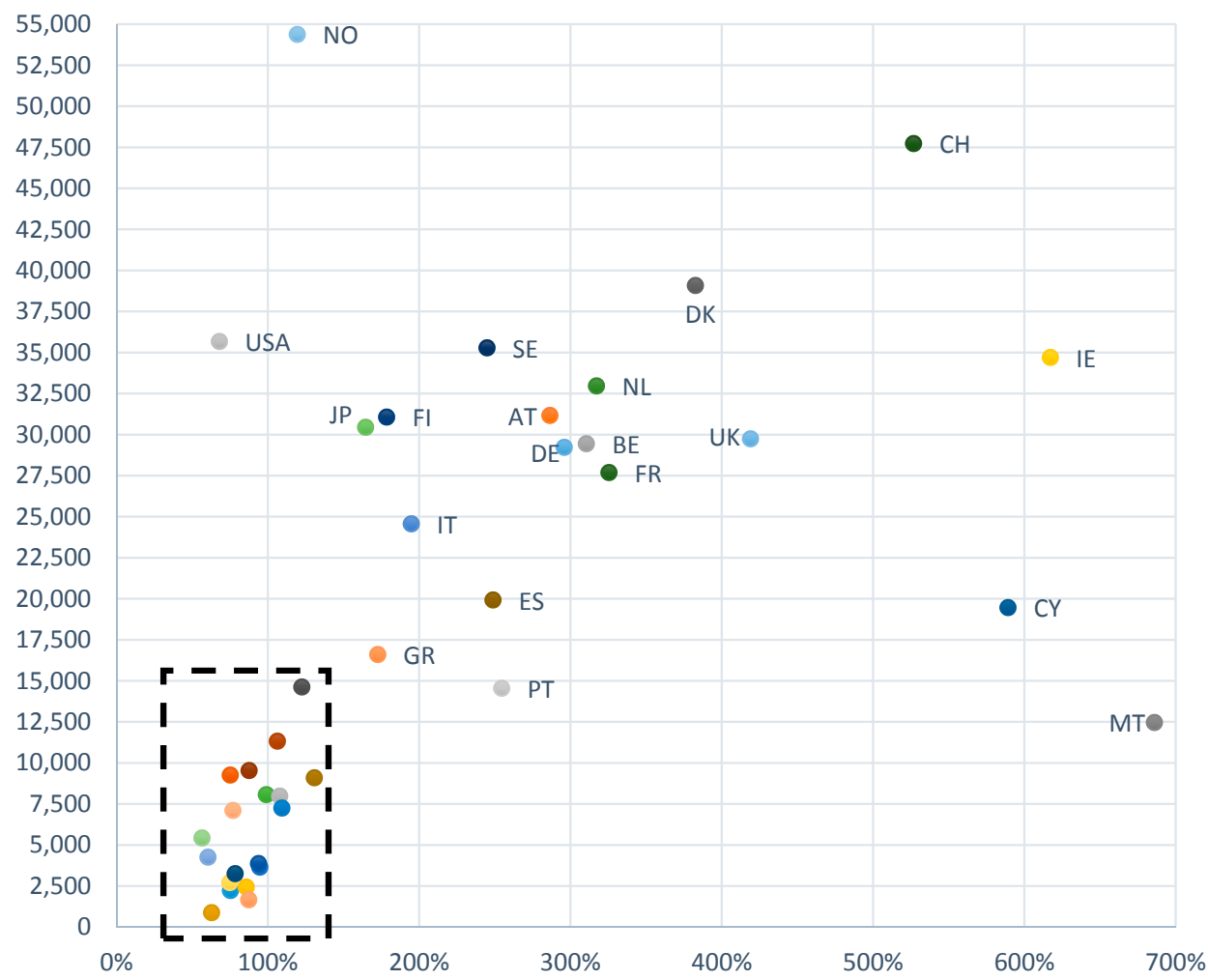

(A)

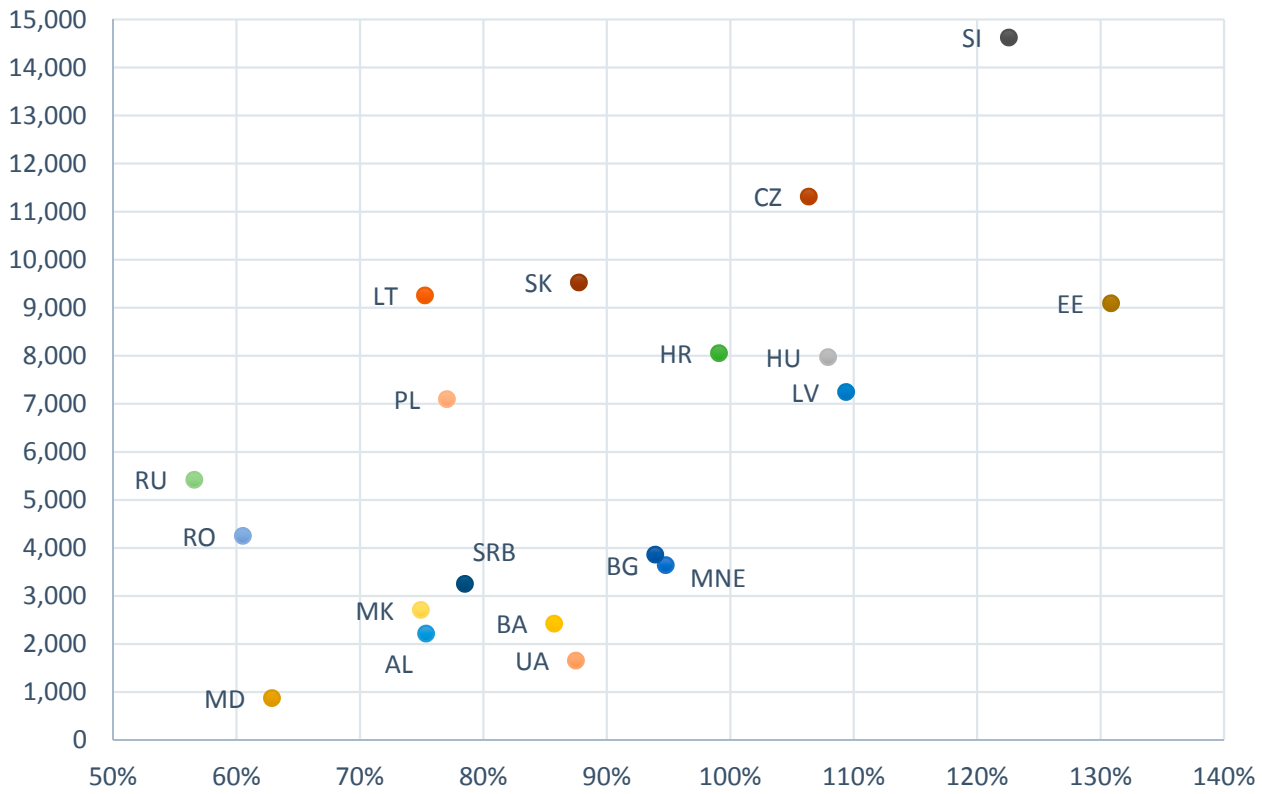

(B)

Figure 4. (A) MFI assets to GDP and GDP per capita in EUR-first part (EU advanced and post-communist countries). Note: Averages for the given country for the period 1995-2014. The values for Luxembourg (3010\% and 64489.9 EUR are not shown for their being evident outliers; based on ECB and World Bank data; (B) MFI assets to GDP and GDP per capita in EUR—second part (CESEEs only). Note: averages for the given country for the period 1995-2014; based on ECB and World Bank data.

We collected data from the World Bank database, the Barro and Lee database, Bankscope, Factset, the Parline database and Helgi Library. We also used hand-collected data on the ownership structure of banks and political parties from 1995 to 2014. Our intention was to cover all 20 post-communist 
countries except Russia, which acts as an investor in the region, especially in former Soviet Union countries. However, owing to the lack of data on the development of human capital, our sample had to be reduced. The panel consists of data for 13 countries from CESEE observed annually over the 1995-2014 period. The countries included in the sample are: Bulgaria, Croatia, Czech Republic, Estonia, Hungary, Latvia, Lithuania, Poland, Romania, Serbia, Slovenia, Slovakia and Ukraine.

Table 3 provides summary statistics for the two dependent variables, 10 control variables and eight financial development measures used in the regressions. The mean values and standard deviations reveal considerable heterogeneity in our sample countries: economic and financial development is far from being uniform within the region and countries of investigation. Notably, although the sample covers a 20-year period and a total of 13 observations is included, it might be expected that the number of observations for which descriptive statistics are provided will be 260 . However, we find it reasonable to provide these statistics only for the observations effectively used in the estimation process (their number varies between the further discussed models, within the $N=121$ to $N=138$ range). There are two reasons why not all the observations are effectively used. First, the panel is unbalanced, which vastly reduced the number of available complete observations. Second, the estimation technique employed in this paper requires the first two waves of observations in the panel to be used only to create the difference of the dependent variable and to play the role of instruments. As a result, observations from the 1995-1996 period are used only "technically", not "effectively".

Table 3. Summary statistics.

\begin{tabular}{|c|c|c|c|c|c|}
\hline & $\mathrm{N}$ of Obs & Mean & Std.dev & Min & Max \\
\hline \multicolumn{6}{|l|}{ Dependent variables } \\
\hline Ln GDP per capita & 138 & 8.615 & 0.748 & 6.722 & 9.911 \\
\hline Ln GDP growth & 138 & 10.712 & 0.856 & 0.072 & 0.245 \\
\hline \multicolumn{6}{|l|}{ Macroeconomic variables } \\
\hline Inflation & 138 & 0.178 & 0.909 & -0.016 & 10.612 \\
\hline Government size & 138 & 0.183 & 0.04 & 0.057 & 0.246 \\
\hline Country's openness to trade & 138 & 0.983 & 0.272 & 0.462 & 1.797 \\
\hline Country's openness to investments & 138 & 0.050 & 0.057 & -0.022 & 0.509 \\
\hline \multicolumn{6}{|l|}{ Institutional characteristics } \\
\hline $\begin{array}{l}\text { Human capital development } \\
\text { Ruling party }\end{array}$ & 138 & 0.153 & 0.046 & 0.072 & 0.246 \\
\hline Party_Left & 138 & 0.058 & 0.235 & 0 & 1 \\
\hline Party_Centre Left & 138 & 0.369 & 0.484 & 0 & 1 \\
\hline Party_Centre Right & 138 & 0.312 & 0.465 & 0 & 1 \\
\hline Party_Right & 138 & 0.101 & 0.303 & 0 & 1 \\
\hline Financial strength index & 138 & 0.186 & 0.127 & -0.212 & 0.376 \\
\hline \multicolumn{6}{|l|}{ Financial development variables } \\
\hline Private credit to GDP & 138 & 0.354 & 0.281 & 0.006 & 1.123 \\
\hline Credit to GDP_development banks & 138 & 0.005 & 0.011 & 0 & 0.055 \\
\hline Credit to GDP_domestic-owned & 138 & 0.081 & 0.083 & 0 & 0.405 \\
\hline Credit to GDP_foreign-owned & 138 & 0.207 & 0.193 & 0 & 0.797 \\
\hline Credit to GDP_state-owned & 138 & 0.061 & 0.099 & 0 & 0.494 \\
\hline Stock market capitalisation to GDP & 138 & 0.164 & 0.129 & 0.0001 & 0.783 \\
\hline Stock market capitalisation of non-financial firms to GDP & 121 & 0.137 & 0.123 & 0.002 & 0.878 \\
\hline $\begin{array}{l}\text { Share of the foreign-owned bank lending in domestic credit } \\
\text { to private sector }\end{array}$ & 138 & 0.502 & 0.288 & 0 & 0.988 \\
\hline Types of bank by ownership & $\mathrm{N}$ & $\%$ & & & \\
\hline Banks owned by development banks & 77 & 2.13 & & & \\
\hline Domestic private-owned banks & 1036 & 28.71 & & & \\
\hline Foreign-owned banks & 2180 & 60.40 & & & \\
\hline State-owned banks & 316 & 8.76 & & & \\
\hline
\end{tabular}


The general specification (1) is usually operationalised as the so-called Barro regression: as far as the methodology of estimation is concerned, our study follows the mainstream in the empirical literature, i.e., the methodology used to estimate most dynamic (autoregressive) panel models. The panel data version used in this paper can be written as:

$$
\Delta \ln G D P_{i t}=\beta_{1} \ln G D P_{i, t-1}+x_{i t}^{\prime} \beta+\alpha_{i}+\varepsilon_{i t}
$$

where $x_{i t}$ is the vector of independent variables (given by $C_{i t}$ and $F_{i t}$ in specification (1), the variables described in Table 2, with the exception of GDP); $\alpha_{i}$ is the country-specific individual effect; $\varepsilon_{i t}$ is the error term (assumed to be the white noise); and $\beta$ and $\beta_{1}$ are the parameters of the model. As stated earlier, we used either GDP or GDP per capita as the dependent variable in different specifications.

As in the original Barro regression, the natural logarithm of GDP and its change were used. On the one hand, this was motivated by the underlying Solow model; on the other hand, it was convenient for endogeneity reasons. It is quite straightforward that $\Delta \ln G D P_{i t}$ is a good approximation of the relative GDP change as long as that change is small, which is almost always the case. However, given the autoregressive character of Equation (3) and the related endogeneity issues, the specification needs to be transformed to the equivalent form before estimation:

$$
\ln G D P_{i t}=\left(\beta_{1}+1\right) \ln G D P_{i, t-1}+x_{i t}^{\prime} \beta+\alpha_{i}+\varepsilon_{i t}
$$

in order to avoid estimator inconsistency (which would not be as straightforward if the relative GDP change were used instead of the logarithm change). While the model is written in the autoregressive form as in Equation (4), the endogeneity issue related to the use of the lagged dependent variable can be solved with the use of its earlier values as instruments. We used the [74] system GMM approach to assess the impact of the regressors on GDP growth, treating most of the regressors as potentially endogenous (with the exception of demographic variables, which are treated as exogenous in the short time period considered). In most of the literature, this approach replaced the earlier [75] estimator, which was found to possess a notable small sample bias. It should be noted that allowing for endogeneity does not necessarily mean that these variables need to be endogenous: this can be viewed as a precaution adopted by most authors, which secures the consistency of the estimator, in view of the endogeneity threat, at the relatively low price of a minor decrease in efficiency. As it is a serious issue whether the applied instruments are themselves exogenous and no functional form is committed, and that the error term needs to be free from autocorrelation in order to avoid the loss of estimator consistency, the estimated specifications are subject to Sargan's over identifying restrictions, as well as Arellano-Bond's autocorrelation tests. Their results are given, along with the estimates of three different specifications of Equation (4) that we modelled. The three specifications differ in terms of the variables of financial development used while controlling for the whole set of conditioning variables. The first specification includes the two traditional variables of financial development, i.e., the ratio of private credit to GDP and the ratio of stock market capitalisation to GDP. The second specification differentiates the ratio of credit to GDP by bank ownership while maintaining the traditional proxy of stock market development; the third specification considers both the new measures of financial deepening to stock market capitalisation of non-financial firms and credit by bank ownership. The ratio of foreign-owned banks lending to total domestic credit to the private sector is present in all three specifications to best control for the real effect of foreign banks.

\section{Estimation Results}

\subsection{Baseline Results}

The results from estimating Equation (4) with GMM regressions on annual data are reported in Tables 4 and 5, first considering real GDP growth as a dependent variable and then real GDP per capita growth. The first column of each table reports the results from a model that considers the traditional variables of financial development, while columns three and four highlight the estimation results including our new measures of financial development. 
Table 4. Determinants of GDP growth.

\begin{tabular}{|c|c|c|c|}
\hline Regressor & Model 1 & Model 2 & Model 3 \\
\hline \multicolumn{4}{|l|}{ Macroeconomic variables } \\
\hline Inflation & $\begin{array}{c}0.02 \\
(0.412) \\
\end{array}$ & $\begin{array}{c}0.003 \\
(0.107) \\
\end{array}$ & $\begin{array}{l}-0.021 \\
(0.460) \\
\end{array}$ \\
\hline Government size & $\begin{array}{c}-0.977 \\
(0.012)^{* *}\end{array}$ & $\begin{array}{c}-0.998 \\
(0.017)^{* *}\end{array}$ & $\begin{array}{c}-0.744 \\
(0.012)\end{array}$ \\
\hline Country's openness to trade & $\begin{array}{c}0.099 \\
(0.121)\end{array}$ & $\begin{array}{c}0.065 \\
(0.226) \\
\end{array}$ & $\begin{array}{c}0.049 \\
(0.346)\end{array}$ \\
\hline Country's openness to investments & $\begin{array}{c}0.246 \\
(0.058)\end{array}$ * & $\begin{array}{c}0.222 \\
(0.065)\end{array}$ * & $\begin{array}{c}0.354 \\
(0.013)^{* * *}\end{array}$ \\
\hline \multicolumn{4}{|l|}{ Institutional characteristics } \\
\hline Human capital development & $\begin{array}{c}0.423 \\
(0.087)\end{array}$ & $\begin{array}{c}0.591 \\
(0.024)^{* *}\end{array}$ & $\begin{array}{c}0.883 \\
(0.012)\end{array}$ ** \\
\hline Party_Left & $\begin{array}{l}-0.045 \\
(0.326)\end{array}$ & $\begin{array}{l}-0.039 \\
(0.308)\end{array}$ & $\begin{array}{c}0.020 \\
(0.649)\end{array}$ \\
\hline Party_Centre Left & $\begin{array}{l}-0.023 \\
(0.137) \\
\end{array}$ & $\begin{array}{l}-0.020 \\
(0.256)\end{array}$ & $\begin{array}{c}0.006 \\
(0.784)\end{array}$ \\
\hline Party_Centre Right & $\begin{array}{c}0.020 \\
(0.317)\end{array}$ & $\begin{array}{c}0.015 \\
(0.473)\end{array}$ & $\begin{array}{c}0.024 \\
(0.354)\end{array}$ \\
\hline Party_Right & $\begin{array}{c}0.042 \\
(0.180) \\
\end{array}$ & $\begin{array}{c}0.037 \\
(0.288) \\
\end{array}$ & $\begin{array}{c}0.096 \\
(0.000)^{* * * *}\end{array}$ \\
\hline Financial strength index & $\begin{array}{c}0.033 \\
(0.766) \\
\end{array}$ & $\begin{array}{l}-0.057 \\
(0.604) \\
\end{array}$ & $\begin{array}{l}-0.026 \\
(0.810) \\
\end{array}$ \\
\hline \multicolumn{4}{|l|}{ Financial system development } \\
\hline $\begin{array}{l}\text { Share of the foreign-owned bank lending in domestic } \\
\text { credit to private sector }\end{array}$ & $\begin{array}{l}-0.023 \\
(0.338)\end{array}$ & $\begin{array}{l}-0.016 \\
(0.690)\end{array}$ & $\begin{array}{l}-0.061 \\
(0.105)\end{array}$ \\
\hline Stock market capitalisation to GDP & $\begin{array}{c}0.127 \\
(0.293)\end{array}$ & $\begin{array}{c}0.139 \\
(0.183)\end{array}$ & \\
\hline Stock market capitalisation of non-financial firms to GDP & & & $\begin{array}{l}-0.032 \\
(0.819)\end{array}$ \\
\hline Credit to private sector to GDP & $\begin{array}{l}-0.128 \\
(0.007)^{* * *}\end{array}$ & & \\
\hline Credit to GDP_development banks & & $\begin{array}{c}1.876 \\
(0.000)^{* * *}\end{array}$ & $\begin{array}{l}2.070 \\
(0.000)^{* * * *}\end{array}$ \\
\hline Credit to GDP_domestic-owned banks & & $\begin{array}{l}-0.073 \\
(0.666)\end{array}$ & $\begin{array}{l}-0.288 \\
(0.008)^{* *}\end{array}$ \\
\hline Credit to GDP_foreign-owned banks & & $\begin{array}{l}-0.194 \\
(0.051)^{*}\end{array}$ & $\begin{array}{l}-0.149 \\
(0.032) *\end{array}$ \\
\hline Credit to GDP_state-owned banks & & $\begin{array}{l}-0.214 \\
(0.000)\end{array}$ & $\begin{array}{l}-0.238 \\
(0.000)^{* * * *}\end{array}$ \\
\hline Cons & $\begin{array}{c}0.510 \\
(0.003)^{* * *}\end{array}$ & $\begin{array}{c}0.481 \\
(0.011)^{* * *}\end{array}$ & $\begin{array}{c}0.332 \\
(0.004)^{* *}\end{array}$ \\
\hline Initial value of GDP growth $\ddagger$ & $\begin{array}{c}0.962 \\
(0.000)^{* * *} \\
\end{array}$ & $\begin{array}{c}0.967 \\
(0.000)^{* * *}\end{array}$ & $\begin{array}{c}0.978 \\
(0.000)^{* * * *}\end{array}$ \\
\hline Arellano-Bond test & -1.661 & -1.791 & -1.5317 \\
\hline Prob > Z (2nd order) & 0.10 & 0.073 & 0.1256 \\
\hline Sargan test & 192.33 & 185.77 & 144.864 \\
\hline Prob > Chi2 & 0.949 & 0.967 & 0.996 \\
\hline Number of observations & 138 & 138 & 121 \\
\hline
\end{tabular}

Note: This table reports the results of a set of dynamic panel estimations aimed at estimating the effect of different measures of financial depth and the characteristics of the financial environment on economic performance. All regressions are estimated with annual data from 1995 to 2014 using first difference GMM estimator. $p$ values of $t$ statistics are in parentheses, with ${ }^{*} p<0.1 ;{ }^{* *} p<0.05 ;{ }^{* * *} p>0.001$. Data source: World Bank database, Bankscope, Factset dataset, hand-collected data, central bank websites. ₹ Estimates of Equation (4) are provided. Consequently, the estimate of $\beta_{1}+1$ is provided with its $p$ value. In order to attain the pure convergence parameter, 1 needs to be subtracted from the quoted estimate. 
Table 5. Determinants of real GDP per capita growth.

\begin{tabular}{|c|c|c|c|}
\hline Regressor & Model 1 & Model 2 & Model 3 \\
\hline \multicolumn{4}{|l|}{ Macroeconomic variables } \\
\hline Inflation & $\begin{array}{c}0.003 \\
(0.024)^{* *}\end{array}$ & $\begin{array}{c}0.006 \\
(0.002)^{* * *}\end{array}$ & $\begin{array}{c}-0.056 \\
(0.090)\end{array}$ \\
\hline Government size & $\begin{array}{c}-0.755 \\
(0.090)^{*}\end{array}$ & $\begin{array}{c}-0.851 \\
(0.041)^{* *}\end{array}$ & $\begin{array}{c}-0525 \\
(0.090)^{*}\end{array}$ \\
\hline Country's openness to trade & $\begin{array}{c}0.108 \\
(0.111)\end{array}$ & $\begin{array}{c}0.065 \\
(0.225)\end{array}$ & $\begin{array}{c}0.089 \\
(0.118)\end{array}$ \\
\hline Country's openness to investments & $\begin{array}{c}0.289 \\
(0.017)^{* *}\end{array}$ & $\begin{array}{c}0.279 \\
(0.008)\end{array}$ & $\begin{array}{c}0.303 \\
(0.020)\end{array}$ \\
\hline \multicolumn{4}{|l|}{ Institutional characteristics } \\
\hline Human capital development & $\begin{array}{c}0.556 \\
(0.245)\end{array}$ & $\begin{array}{c}0.828 \\
(0.005)^{* * * *}\end{array}$ & $\begin{array}{c}0.886 \\
(0.083) \text { * }\end{array}$ \\
\hline Party_Left & $\begin{array}{l}-0.054 \\
(0.210)\end{array}$ & $\begin{array}{c}-0.086 \\
(0.086)^{*}\end{array}$ & $\begin{array}{c}0.050 \\
(0.204)\end{array}$ \\
\hline Party_Centre Left & $\begin{array}{l}-0.024 \\
(0.111)\end{array}$ & $\begin{array}{l}-0.057 \\
(0.081)^{*}\end{array}$ & $\begin{array}{c}0.001 \\
(0.966)\end{array}$ \\
\hline Party_Centre Right & $\begin{array}{c}0.029 \\
(0.091)\end{array}$ & $\begin{array}{c}0.017 \\
(05363)\end{array}$ & $\begin{array}{c}0.035 \\
(0.167)\end{array}$ \\
\hline Party_Right & $\begin{array}{c}0.039 \\
(0.099) *\end{array}$ & $\begin{array}{l}-0.036 \\
(0.214)\end{array}$ & $\begin{array}{c}0.087 \\
(0.002)^{* * * *}\end{array}$ \\
\hline Financial strength index & $\begin{array}{c}0.039 \\
(0.783)\end{array}$ & $\begin{array}{l}-0.061 \\
(0.640)\end{array}$ & $\begin{array}{l}-0.021 \\
(0.832)\end{array}$ \\
\hline \multicolumn{4}{|l|}{ Financial system development } \\
\hline $\begin{array}{l}\text { Share of the foreign-owned bank lending in domestic } \\
\text { credit to private sector }\end{array}$ & $\begin{array}{l}-0.031 \\
(0.323)\end{array}$ & $\begin{array}{l}-0.045 \\
(0.227)\end{array}$ & $\begin{array}{l}-0.089 \\
(0.007) * * *\end{array}$ \\
\hline Stock market capitalisation to GDP & $\begin{array}{l}0.076 \\
(0.541)\end{array}$ & $\begin{array}{c}0.100 \\
(0.343)\end{array}$ & \\
\hline Stock market capitalisation of non-financial firms to GDP & & & $\begin{array}{l}-0.050 \\
(0.736)\end{array}$ \\
\hline Credit to private sector to GDP & $\begin{array}{c}-0.143 \\
(0.039)^{* *}\end{array}$ & & \\
\hline Credit to GDP_development banks & & $\begin{array}{c}2.30 \\
(0.000)^{* * *}\end{array}$ & $\begin{array}{c}2.230 \\
(0.001)^{* * * *}\end{array}$ \\
\hline Credit to GDP_domestic-owned banks & & $\begin{array}{l}-0.157 \\
(0.344)\end{array}$ & $\begin{array}{l}-0.313 \\
(0.029)\end{array}$ \\
\hline Credit to GDP_foreign-owned banks & & $\begin{array}{l}-0.201 \\
(0.077)\end{array}$ & $\begin{array}{l}-0.108 \\
(0.207)\end{array}$ \\
\hline Credit to GDP_state-owned banks & & $\begin{array}{c}-0.274 \\
(0.000)^{* * *}\end{array}$ & $\begin{array}{l}-0.223 \\
(0.012)^{* *}\end{array}$ \\
\hline Cons & $\begin{array}{c}0.143 \\
(0.349)\end{array}$ & $\begin{array}{c}0.134 \\
(0.346)\end{array}$ & $\begin{array}{c}0.396 \\
(0.021)^{* *}\end{array}$ \\
\hline Initial value of GDP $\ddagger$ & $\begin{array}{c}0.989 \\
(0.000)^{* * *}\end{array}$ & $\begin{array}{c}0.967 \\
(0.000)^{* * *}\end{array}$ & $\begin{array}{c}0.958 \\
(0.000)^{* * * *}\end{array}$ \\
\hline Arellano-Bond test & -1.65 & -1.806 & -1.5633 \\
\hline Prob > Z (2nd order) & 0.10 & 0.10 & 0.118 \\
\hline Sargan test & 195.07 & 186.57 & 146.912 \\
\hline Prob > Chi2 & 0.933 & 0.964 & 0.994 \\
\hline Number of observations & 138 & 138 & 121 \\
\hline
\end{tabular}

Note: This table reports the results of a set of dynamic panel estimations aimed at estimating the effect of different measures of financial depth and the characteristics of the financial environment on economic performance. All regressions are estimated with annual data from 1995 to 2014 using first difference GMM estimator. $p$ values of $t$ statistics are in parentheses, with ${ }^{*} p<0.1 ;{ }^{* *} p<0.05 ;{ }^{* * *} p>0.001$. Data source: World Bank database, Bankscope, Factset dataset, hand-collected data, central bank websites. ₹ Estimates of Equation (4) are provided. Consequently, the estimate of $\beta_{1}+1$ is provided with its $p$ value. In order to attain the pure convergence parameter, 1 needs to be subtracted from the quoted estimate. 
Our results confirm theoretical predictions about macro and institutional variables: the signs are as expected, although the statistical significance is not always confirmed. In all the specifications, two variables are statistically significant and have a non-negligible impact on growth: the ratio of foreign direct investment to GDP (positive effect) and government size (negative effect). Human capital development is also positively correlated to growth: the higher the population with tertiary education, the higher the (positive) effect on growth prospects. These results confirm the findings of existing macroeconomic studies that generally suggest a positive role of FDI in economic growth, especially when the country has a highly educated workforce that allows it to exploit FDI spill-overs [76,77]. We do not confirm the role of country's openness to trade in developing countries (as [32]). This may be explained by extensive foreign trade, even during the times of communism in the CESEE region and the "specialisation" of those countries in certain goods, services or commodities. After the start of economic and political transformations, foreign trade was partly redirected to advanced economies.

The effect of inflation on economic growth was either non-significant or positive and contrasted with the general consensus about the adverse effects of inflation on real growth. Our results could be explained within the strand of recent research highlighting a non-linear relationship between the two variables [78,79]: at lower rates of inflation, the relationship is not significant or even positive. Indeed, the estimate of the threshold level for developing countries was $1 \%-12 \%$ [79], and our sample inflation rates ranged from negative to a maximum of $10 \%$, confirming the above explanation.

As regards the set of dummies introduced to control for the political option that rules the country, the results were mixed but not statistically significant (reference category is "centre"). One minor exception was represented by the coefficient of right-wing parties (positively correlated to growth). This result could be explained by the fact that right-wing parties are usually in favour of lean governments; in this vein, the finding supports the fact that government size is negatively correlated to economic growth.

Banking sector conditions (FSI) do not seem to play a significant role in improving economic growth. Although the relationship between a country's rate of economic growth and its financial development has been studied in depth, few studies have sought to explain how this link operates during periods of financial instability [80,81]. More recently, using different measures, financial instability was found to have a negative effect on economic growth in the $27 \mathrm{EU}$ member states during the period 1998-2011 [82]. The non-existence of this relationship may be due to the fact that the banking sectors in CESEEs were not directly affected by the global financial crisis, which could have directly diminished economic growth. At the same time, transformation crises in the 1990s were at the very beginning of our sample period, which might not have given a full picture about the impact of banking sector stability on growth in CESEEs throughout the sampling period.

Regarding the impact of the financial system on economic growth, our results are not in line with the mainstream literature analysing the finance-growth nexus in advanced economies. Although complete unanimity does not exist, the bulk of empirical research on the mechanisms through which finance affects growth suggests that countries with a higher ratio of credit to the private sector (to GDP) and a higher market capitalisation (to GDP) grow faster [8]. Moreover, recent literature has found that the conventional positive finance-growth link weakens when post-1990 data are used [83], findings supported by our research.

Stock markets are not significantly related to growth, not even when considering the sole capitalisation of non-financial firms. In fact, large and liquid equity markets play an important role in easing capital accumulation, fostering corporate governance, facilitating risk management and stimulating the production of information about firms: only in the presence of these features can we expect a positive impact on economic growth. Indeed, the countries in the sample under investigation do not share the same level of depth of the financial markets, and our result is in line with [84], who found no evidence of growth effects stemming from the Romanian Stock Exchange. In order to disentangle the actual role of financial markets, the next paragraph distinguishes between countries accessing the EU in 2004, whose financial markets are expected to be more liquid and large, 
and countries entering the EU after 2004 or that have not yet entered, which typically have newly created stock markets.

However, credit provided by the banking system to the private sector (firms and households) seems to depress a country's economic prospects. The low and negative coefficient for the credit to GDP ratio confirms the weakness of the finance-growth link in bank-based developing economies such as CESEEs $[22,25,26]$.

As far as the role of foreign banks is concerned, we found that the market share of foreign banks in local credit markets is negatively associated with economic growth, though not significantly so. Considering that recent empirical contributions cast much doubt on the ability of foreign bank subsidiaries to act as shock absorbers in host countries [36,73], we are led to conclude that the strategy of a considerable entry of foreign banks in local credit markets has not guaranteed the supposed positive effects on financial innovation and development and, ultimately, economic growth in host countries.

This evidence is also confirmed by the inclusion of the second variable that distinguishes the credit provided according to bank ownership. In fact, the ownership structure of the sample banks reveals that only banks owned by development banks have a positive impact on growth. All other banks (foreign-owned, state-owned and domestic privately owned) determine negative growth effects. The credit composition of these banks' lending could represent one possible explanation for these findings. Banks owned by development banks are expected to grant credit to finance infrastructure and long-term projects promoted by private firms or public bodies. Recent contributions have highlighted that the banking sector plays a growth-supporting role in economic growth to the extent that it lends to enterprises and not to households [83,85-88]. As highlighted by [83] on a sample of 34 countries, with data available on credit composition, credit to households is likely to result in lower savings and therefore in lower growth. With specific reference to the 27 European countries, evidence was provided that household credit undermines economic growth [86]. It could be of interest to investigate the credit composition of the loan portfolios of our sample banks; however, this information would not be available at the bank level in most cases.

Another explanation for our results has been highlighted by [24,27]: both studies found that a rise in the amount of credit does not seem to accelerate economic growth for a sample of transition countries similar to ours. The main reasons for this are traced to the numerous banking crises experienced in transition countries-in the 1990s and later on after 2008 and 2010 - and the soft budget constraints that remain prevalent in many of these countries. Lending to enterprises applying soft budget constraints is at risk of financing inefficient investments and generating financial loss. As a result, growth in credit is not profitable. Because of these specific characteristics, the amount of credit allocated to the private sector has not always been sustainable, and in some cases, it has been negatively and significantly associated with economic growth. Indeed, other studies have identified that the increased incidence of banking crises is a contributing factor to the "disappearance" —or reduced importance—of the empirical link between finance and growth [89].

All in all, our evidence casts doubts on the assumption that foreign banks are a positive and efficient addition to local markets, able to promote innovation and competition and ultimately fostering economic growth.

\subsection{Stock Markets Developments and Global Financial Crises: A Further Investigation}

In order to gain a deeper insight into our results, we ran our model considering two different sub-samples: previous accounts for a different time span, i.e., excluding the GFC; the latter focuses on CESEE countries that first accessed the EU in 2004. These countries are the Czech Republic, Estonia, Hungary, Latvia, Lithuania, Poland, Slovenia and Slovakia (the number of observations to run proper regressions is too low to present the results of sub-samples including the GFC time, as well as the non-accession countries included in our full sample). Given that these named countries were the first to conform to the EU's "economic requirements", we expected that they would represent the "frontier" of financial development among our sample countries. Therefore, this sub-sample could be 
helpful in disentangling the precise role of more liquid and large financial markets. There also exists a strong statistical reason to perform the sub-sample analysis when it is believed that the process is not essentially homogeneous across the sample. Pre-assuming the process's homogeneity irrespective of the time (whether it is before or after GFC; which group of countries) might result in a general functional form error and, as a consequence, in the loss of estimator's consistency, if the assumption is too strong and not fulfilled. In view of the above, we perform the sub-sample analysis as well.

Table 6 reports on the estimation results for this sub-sample of countries for the overall sample period (1995-2014). For reasons of brevity, we only report estimation results for the dependent variable "GDP growth", as similar results were obtained with respect to "GDP per capita growth"; similar considerations apply to Table 7 . Ceteris paribus, stock markets now hold a negative and significant sign. While all the other explanatory variables maintained their sign and, in most cases, their statistical significance, the stock markets reverted to their potential influence on economic growth. We confirm our initial hypothesis that stock markets are relevant in influencing economic growth to the extent that they are large and liquid. Indeed, the coefficient is now statistically significant; however, the negative sign hinders us from inferring a positive role for stock markets on economic growth. One possible explanation may be linked to the specific sampling period under investigation, characterised by the global financial crisis from 2008 to 2014.

Table 6. Determinants of GDP growth—accession countries.

\begin{tabular}{|c|c|c|c|}
\hline Regressor & Model 1 & Model 2 & Model 3 \\
\hline \multicolumn{4}{|l|}{ Macroeconomic variables } \\
\hline Inflation & $\begin{array}{c}0.519 \\
(0.006)^{* *}\end{array}$ & $\begin{array}{c}0.504 \\
(0.004)^{* *}\end{array}$ & $\begin{array}{c}0.594 \\
(0.007)^{* *}\end{array}$ \\
\hline Government size & $\begin{array}{c}-1.794 \\
(0.000)^{* * *}\end{array}$ & $\begin{array}{c}-1.836 \\
(0.000)^{* * *}\end{array}$ & $\begin{array}{c}-1.867 \\
(0.000)^{* * *}\end{array}$ \\
\hline Country's openness to trade & $\begin{array}{c}0.005 \\
(0.898)\end{array}$ & $\begin{array}{c}-0.0004 \\
(0.991)\end{array}$ & $\begin{array}{c}0.013 \\
(0.796)\end{array}$ \\
\hline Country's openness to investments & $\begin{array}{c}0.373 \\
(0.000)^{* * *}\end{array}$ & $\begin{array}{c}0.400 \\
(0.002)^{* *}\end{array}$ & $\begin{array}{c}0.379 \\
(0.009)^{* * *}\end{array}$ \\
\hline \multicolumn{4}{|l|}{ Institutional characteristics } \\
\hline Human capital development & $\begin{array}{c}0.995 \\
(0.001)^{* * *}\end{array}$ & $\begin{array}{c}1.179 \\
(0.019)^{* *}\end{array}$ & $\begin{array}{c}1.102 \\
(0.007)^{* *}\end{array}$ \\
\hline Party_Left & $\begin{array}{c}-0.044 \\
(0.042)^{* *}\end{array}$ & $\begin{array}{c}-0.038 \\
(0.063)^{*}\end{array}$ & $\begin{array}{c}-0.053 \\
(0.019)^{* *}\end{array}$ \\
\hline Party_Centre Left & $\begin{array}{c}-0.044 \\
(0.000)^{* * *}\end{array}$ & $\begin{array}{c}-0.044 \\
(0.000)^{* * *}\end{array}$ & $\begin{array}{c}-0.046 \\
(0.000)^{* * *}\end{array}$ \\
\hline Party_Centre Right & $\begin{array}{c}0.008 \\
(0.429)\end{array}$ & $\begin{array}{c}0.007 \\
(0.592)\end{array}$ & $\begin{array}{c}-0.005 \\
(0.000)^{* * *}\end{array}$ \\
\hline Party_Right & $\begin{array}{c}0.090 \\
(0.000)^{* * *}\end{array}$ & $\begin{array}{c}0.095 \\
(0.000)^{* * *}\end{array}$ & $\begin{array}{c}0.096 \\
(0.000)^{* * *}\end{array}$ \\
\hline Financial strength index & $\begin{array}{c}0.065 \\
(0.256)\end{array}$ & $\begin{array}{c}0.046 \\
(0.486)\end{array}$ & $\begin{array}{c}0.092 \\
(0.251)\end{array}$ \\
\hline \multicolumn{4}{|l|}{ Financial system development } \\
\hline $\begin{array}{l}\text { Share of the foreign-owned bank lending in domestic } \\
\text { credit to private sector }\end{array}$ & $\begin{array}{l}-0.037 \\
(0.891)\end{array}$ & $\begin{array}{c}0.001 \\
(0.983)\end{array}$ & $\begin{array}{c}0.017 \\
(0.720)\end{array}$ \\
\hline Stock market capitalisation to GDP & $\begin{array}{c}-0.188 \\
(0.008)^{* *}\end{array}$ & $\begin{array}{c}-0.200 \\
(0.035) * *\end{array}$ & \\
\hline Stock market capitalisation of non-financial firms to GDP & & & $\begin{array}{l}-0.253 \\
(0.005)^{* * *}\end{array}$ \\
\hline Credit to private sector to GDP & $\begin{array}{c}-0.121 \\
(0.000) * * *\end{array}$ & & \\
\hline
\end{tabular}


Table 6. Cont.

\begin{tabular}{cccc}
\hline Regressor & Model 1 & Model 2 & Model 3 \\
\hline Credit to GDP_development banks & & 0.604 & 0.458 \\
& & $(0.423)$ & $(0.517)$ \\
\hline \multirow{2}{*}{ Credit to GDP_domestic-owned banks } & & -0.117 & -0.111 \\
& & $(0.292)$ & $(0.338)$ \\
\hline \multirow{2}{*}{ Credit to GDP_foreign-owned banks } & -0.182 & -0.194 \\
Credit to GDP_state-owned banks & $(0.123)$ & $(0.049)^{* *}$ \\
\hline \multirow{2}{*}{ Cons } & -0.136 & -0.087 \\
& & $(0.020)^{* * *}$ & $(0.195)$ \\
\hline \multirow{2}{*}{ Initial value of GDP per capita $\ddagger$} & 0.565 & 0.521 & 0.541 \\
Arellano-Bond test & $0.001)^{* * *}$ & $(0.004)^{* *}$ & $(0.000)^{* * *}$ \\
\hline Prob $>$ Z (2nd order) & 0.974 & 0.978 & 0.975 \\
Sargan test & -1.336 & -1.366 & -1.384 \\
\hline Prob $>$ Chi2 & 0.181 & 0.181 & 0.166 \\
\hline Number of observations & 104.435 & 98.79 & 104.19 \\
\hline
\end{tabular}

Note: This table reports the results of a set of dynamic panel estimations aimed at estimating the effect of different measures of financial depth and the characteristics of the financial environment on economic performance of a sub-sample of countries that accessed the EU before 2004. All regressions are estimated with annual data from 1995 to 2014 using first difference GMM estimator. $p$ values of $t$ statistics are in parentheses, with ${ }^{*} p<0.1$; ${ }^{* *} p<0.05$; *** $p>0.001$. Data source: World Bank database, Bankscope, Factset dataset, hand-collected data, central bank websites. $¥$ Estimates of Equation (4) are provided. Consequently, the estimate of $\beta_{1}+1$ is provided with its $p$ value. In order to attain the pure convergence parameter, 1 needs to be subtracted from the quoted estimate.

Unfortunately, we could not further investigate the issue levering on this sub-sample of countries, given the limited number of observations available. For this reason, we analysed the effect of the GFC, considering the whole sample of countries and focusing on a fraction of the sample period from 1995 to 2007 (Table 7), i.e., excluding the recent global financial crisis.

Table 7. Determinants of GDP growth (1995-2007).

\begin{tabular}{cccc}
\hline Regressor & Model 1 & Model 2 & Model 3 \\
\hline Macroeconomic variables & & & \\
\hline Inflation & 0.005 & 0.006 & -0.078 \\
& $(0.008)^{* * *}$ & $(0.000)^{* * *}$ & $(0.000)^{* * *}$ \\
\hline \multirow{2}{*}{ Government size } & -0.832 & -0.859 & -0.722 \\
& $(0.001)^{* * *}$ & $(0.019)$ & $(0.004)^{* * *}$ \\
\hline Country's openness to trade & 0.003 & -0.162 & -0.048 \\
& $(0.928)$ & $(0.675)$ & $(0.419)$ \\
\hline Country's openness to investments & 0.085 & 0.079 & 0.157 \\
& $(0.425)$ & $(0.436)$ & $(0.168)$ \\
\hline Institutional characteristics & & & \\
\hline \multirow{2}{*}{ Human capital development } & 0.251 & 0.342 & -0.301 \\
& $(0.340)$ & $(0.232$ & $(0.541)$ \\
\hline \multirow{2}{*}{ Party_Left } & - & - & - \\
\hline \multirow{2}{*}{ Party_Centre Left } & & & -0.028 \\
\hline \multirow{2}{*}{ Party_Centre Right } & -0.026 & -0.024 & $(0.146)$ \\
\hline
\end{tabular}


Table 7. Cont.

\begin{tabular}{|c|c|c|c|}
\hline Regressor & Model 1 & Model 2 & Model 3 \\
\hline Party_Right & $\begin{array}{c}0.019 \\
(0.560)\end{array}$ & $\begin{array}{c}0.014 \\
(0.686)\end{array}$ & $\begin{array}{c}0.039 \\
(0.094) *\end{array}$ \\
\hline Financial strength index & $\begin{array}{l}-0.06 \\
(0.473)\end{array}$ & $\begin{array}{l}-0.138 \\
(0.187)\end{array}$ & $\begin{array}{l}-0.167 \\
(0.029) * *\end{array}$ \\
\hline \multicolumn{4}{|l|}{ Financial system development } \\
\hline $\begin{array}{l}\text { Share of the foreign-owned bank lending in domestic } \\
\text { credit to private sector }\end{array}$ & $\begin{array}{l}-0.030 \\
(0.228)\end{array}$ & $\begin{array}{l}-0.042 \\
(0.404)\end{array}$ & $\begin{array}{l}-0.107 \\
(0.02)^{* *}\end{array}$ \\
\hline Stock market capitalisation to GDP & $\begin{array}{c}0.169 \\
(0.002)^{* * *}\end{array}$ & $\begin{array}{c}0.191 \\
(0.000)^{* * *}\end{array}$ & \\
\hline Stock market capitalisation of non-financial firms to GDP & & & $\begin{array}{c}0.216 \\
(0.000) * * *\end{array}$ \\
\hline Credit to private sector to GDP & $\begin{array}{l}-0.007 \\
(0.859)\end{array}$ & & \\
\hline Credit to GDP_development banks & & $\begin{array}{c}1.513 \\
(0.022)^{* *}\end{array}$ & $\begin{array}{l}1.084 \\
(0.159)\end{array}$ \\
\hline Credit to GDP_domestic-owned banks & & $\begin{array}{c}0.023 \\
(0.926) \\
\end{array}$ & $\begin{array}{l}-0.165 \\
(0.471) \\
\end{array}$ \\
\hline Credit to GDP_foreign-owned banks & & $\begin{array}{l}-0.063 \\
(0.643)\end{array}$ & $\begin{array}{c}0.159 \\
(0.242)\end{array}$ \\
\hline Credit to GDP_state-owned banks & & $\begin{array}{c}-0.155 \\
(0.025)^{* *}\end{array}$ & $\begin{array}{c}-0.217 \\
(0.004)^{* *}\end{array}$ \\
\hline Cons & $\begin{array}{c}0.541 \\
(0.001)^{* * *}\end{array}$ & $\begin{array}{c}0.537 \\
(0.003)^{* * *}\end{array}$ & $\begin{array}{c}0.749 \\
(0.002)^{* * *}\end{array}$ \\
\hline Initial value of GDP per capita $\ddagger$ & $\begin{array}{c}0.967 \\
(0.000) * * *\end{array}$ & $\begin{array}{c}0.970 \\
(0.000) * * * *\end{array}$ & $\begin{array}{c}0.962 \\
(0.000)^{* * *}\end{array}$ \\
\hline Arellano-Bond test & -0.677 & -0.780 & -0.0592 \\
\hline Prob > Z (2nd order) & 0.498 & 0.435 & 0.554 \\
\hline Sargan test & 151.793 & 147.519 & 103.06 \\
\hline Prob > Chi2 & 0.778 & 0.80 & 0.941 \\
\hline Number of observations & 103 & 103 & 82 \\
\hline
\end{tabular}

Note: This table reports the results of a set of dynamic panel estimations aimed at estimating the effect of different measures of financial depth and the characteristics of the financial environment on economic performance. All regressions are estimated with annual data from 1995 to 2007 using first difference GMM estimator. $p$ values of $t$ statistics are in parentheses, with ${ }^{*} p<0.1 ; * * p<0.05$; *** $p>0.001$. Data source: World Bank database, Bankscope, Factset dataset, hand-collected data, central bank websites. ${ }^{\ddagger}$ Estimates of Equation (4) are provided. Consequently, the estimate of $\beta_{1}+1$ is provided with its $p$ value. In order to attain the pure convergence parameter, 1 needs to be subtracted from the quoted estimate.

What is immediately apparent is that the crises that began in 2008 have changed the role of stock markets in CESEE countries, though not that of bank credit to the private sector. Ceteris paribus, the role of stock markets as a whole, with specific reference to non-financial firm capitalisation, was conducive to higher economic growth before the GFC. A one-percent increase in stock market capitalisation is reflected in GDP growth ranging between 0.16 and $0.2 \%$. This contrasts with our previous results that consider the overall period of 1995-2014, for which stock markets were either not significant or even unfavourable to economic growth. This result seems to be driven more by crisis-related considerations than by the fact that stock markets in the CESEE region are still underdeveloped, in terms of size and liquidity, with respect to the standards of an advanced economy, as initially suggested. Indeed, the sub-prime crisis and subsequent European sovereign debt crisis were a major hit on CESEE stock markets (in late 2008, the MSCI EMEE index (covering the Czech Republic, Hungary, Poland and Russia) lost more than $50 \%$ of its value in two months, much more than any other emerging market region in the world (see [90])) and financial markets in general: since 2008, massive falls in asset prices were registered, including stock prices, fixed income securities and-in the case of some CESEE 
countries-house prices [91]. The downward correction was particularly pronounced in the Baltic and SEE countries, suggesting that countries with rather pronounced vulnerabilities and a higher degree of financial integration tended to be more severely affected [90].

On the contrary, no different pattern was detected before the GFC with respect to the ratio of bank credit to the private sector: our results did not change, and the variable was either statistically not significant or even detrimental to GDP growth, as in the case of state-owned banks, even in the pre-crisis period. Similar considerations apply to the presence of foreign-owned banks: the higher their market share in local credit markets, the lower the economic growth of the host country.

\section{Conclusions}

Our paper focuses on the role of financial development in the economic growth of CESEE countries in the post-communist era, the GFC and the period afterwards. In particular, we analyse whether CESEE countries have benefited from foreign-owned bank presence in terms of higher economic growth. Although complete unanimity does not exist, the bulk of empirical research on the mechanisms through which finance affects growth suggests that countries with a higher ratio of credit to the private sector to GDP and a higher market capitalisation to GDP grow faster. Our findings cast doubt on these results, at least in the case of CESEE economies. Moreover, our results challenge the idea that foreign-owned banks are a source of innovation with positive spill-over effects in local banking markets.

The majority of studies, conducted either at the beginning of the twenty-first century or even more recently, point to a limited, if not non-existent, relationship between financial development (bank and stock markets) and economic growth for CESEE countries. These findings have also been confirmed in other regions when post-1990 data have been used.

Nonetheless, the financial systems in CESEE countries have evolved considerably from their starting point at the beginning of the 1990s, and it would seem quite odd, prima facie, that this development had no effect on the economic growth of these economies.

Indeed, we find that bank credit could be an important source of economic growth to the extent that banks owned by development banks are involved in the process of providing credit to the private sector. They could be involved in many activities, with diversified scope and focus, targeting a broad base of customers or specific types of customers, such as SMEs or start-ups. Moreover, they could be involved in infrastructural projects that are regarded as growth-related. However, the number and relative size of such banks in CESEE countries is not considerable, which may explain why the overall credit to the private sector is far from being a catalyst of growth.

Finally, with respect to the role of stock markets, we underline a positive contribution to economic growth, except for extremely volatile periods, as at the start of 2008. Since periods of boom and bust typically characterise stock markets and are not easy to predict, excessive leverage on stock markets could be harmful to the real economy.

Our findings indicate that the future research agenda should include microeconomic data on credit composition according to the type of customer and by bank ownership, in order to qualify and clarify how bank credit policies targeted at specific market segments can foster or dampen economic growth. Foreign-owned banks in CESEE have preferred to lend primarily to households (rather than to enterprises) to enjoy "cream-skimming" in a nascent business area and to avoid or limit the adverse selection problems that typically affect the supply of loans to local firms by new entrants. This may explain the limited role of bank credit in boosting economic growth and the negative effects of foreign lending on the growth prospects of the host country. A thorough analysis of the process of bancarisation in CESEE countries warrants further investigation for the negative effects that household indebtedness may have on economic development. Taking into account the market share of foreign-owned banks in CESEE countries, these results may imply some public policy measures. If the foreign ownership of banks does not support economic growth, the reduction of their market share may be reconsidered, on condition that there is enough domestic capital to invest in the banking sector. Some countries, 
such as Hungary and Poland, decided to undertake such measures in recent years. However, it was mostly the result of the parent company decision to "exit" the market, either because of unfavourable financial conditions in the home country (e.g., Unicredit) or because of an evolving global strategy (e.g., GE Capital). Further in-depth analysis should be considered of the role of foreign-owned banks in each host country, taking into account its capacities and development potential.

Acknowledgments: This paper has been prepared within the framework of the Polish National Science Centre (NCN) financing-research project number UMO-2014/13/B/HS4/01619. The authors would like to thank anonymous referees and discussant and participants to the International Rome Conference on Money Banking and Finance (2016) for their valuable comments and suggestions.

Author Contributions: Paola Bongini: review of literature, preparation of data, selection of variables, discussion of results, and conclusions; Małgorzata Iwanicz-Drozdowska: review of literature, preparation of data, selection of variables, and conclusions; Paweł Smaga: review of literature, and preparation of data and figures; Bartosz Witkowski: selection of modelling techniques, modelling, and testing.

Conflicts of Interest: The authors have not identified any conflict of interest.

\section{Abbreviations}

CAMELS

\section{CEE}

CESEE

EBRD

ECB

ETA

FDI

FSI

GDP

GFC

GMM

L_impair_to_TA

Liquid_A_to_Funding

Loans_to_Deposits

NPL

MFI

ROA

WB database

\author{
"C" for capital adequacy, " $\mathrm{A}$ " for assets quality, " $\mathrm{M}$ " for management, \\ " $E$ " for earnings, " $L$ " for liquidity and " $S$ " for sensitivity to market risk \\ Central and Eastern Europe \\ Central, Eastern and South-Eastern Europe \\ European Bank for Reconstruction and Development \\ European Central Bank \\ Equity capital to total assets \\ Foreign direct investment \\ Financial strength index \\ Gross Domestic Product \\ Global financial crisis \\ Generalised method of moments \\ Ratio of impairment charges to total assets \\ Ratio of liquid assets to total funding \\ Ratio of loans to customers to deposits from customers \\ Non-performing loans ratio \\ Monetary financial institution \\ Return on assets ratio \\ World Bank database
}

\section{References}

1. Claessens, S.; van Horen, N. Foreign Banks: Trends and Impact. J. Money Credit Bank. 2014, 46, 295-326. [CrossRef]

2. Gurley, C.T.; Shaw, E.S. Financial aspects of economic development. Am. Econ. Rev. 1955, 45, 515-538.

3. Goldsmith, R.W. Financial Structure and Development; Yale University Press: New Haven, CT, USA, 1969.

4. McKinnon, R.I. Money and Capital in Economic Development; The Brookings Institution: Washington, DC, USA, 1973.

5. King, R.G.; Levine, R. Finance and Growth. Schumpeter Might Be Right. Q. J. Econ. 1993, 108, 717-738. [CrossRef]

6. Atje, R.; Jovanovic, B. Stock Markets and Development. Eur. Econ. Rev. 1993, 37, 632-640. [CrossRef]

7. Levine, R. Finance and Growth: Theory and Evidence. In Handbook of Economic Growth; Aghion, P., Durlauf, S.N., Eds.; Elsevier: Amsterdam, The Netherlands, 2005.

8. Beck, T. The Econometrics of Finance and Growth; World Bank Policy Research Working Paper Series; World Bank: Washington, DC, USA, 2008; Volume 2, pp. 1-51.

9. Beck, T. The Role of Finance in Economic Development: Benefits, Risks, and Politics; European Banking Center Discussion Paper No. 2011-038; Tilburg University: Tilburg, The Netherlands, 2011. 
10. Arestis, P.; Chortareas, G.; Magkonis, G. The financial development and growth nexus: A meta analysis. J. Econ. Surv. 2015, 29, 549-565. [CrossRef]

11. Valickova, P.; Havranek, T.; Horvath, R. Financial Development and economic growth: A meta analysis. J. Econ. Surv. 2015, 29, 506-526. [CrossRef]

12. Khan, A. The Finance and Growth Nexus, Business Review; Federal Reserve Bank of Philadelphia: Philadelphia, PA, USA, 2000.

13. Beck, T. Finance for Development: A Research Agenda. ESRC-DFID DEGRP Research Report. 2013. Available online: https://assets.publishing.service.gov.uk/media/57a08a48e5274a27b200050b/FinanceDevelopment-Research-Report-September-2013.pdf (accessed on 15 January 2017).

14. Dawson, P.J. Financial development and economic growth: A panel approach. Appl. Econ. Lett. 2010, 17, 741-745. [CrossRef]

15. Schmidt, R.H.; Hryckiewicz, A. Financial Systems_Importance, Differences and Convergence; IMFS Working Paper Series No. 4; Institute for Monetary and Financial Stability, Johann Wolfgang Goethe-Universität: Frankfurt am Main, Germany, 2006.

16. King, R.G.; Levine, R. Finance, Entrepreneurship, and Growth: Theory and Evidence. J. Monet. Econ. 1993, 32, 513-542. [CrossRef]

17. Rousseau, P.; Wachtel, P. Financial Intermediation and Economic Performance: Historical Evidence from Five Industrialized Countries. J. Money Credit Bank. 1998, 30, 657-678. [CrossRef]

18. Levine, R.; Loayza, N.; Beck, T. Financial intermediation and growth: Causality and causes. J. Monet. Econ. 2000, 46, 31-77. [CrossRef]

19. Levine, R.; Zervos, S. Stock Markets, Banks, and Economic Growth. Am. Econ. Rev. 1998, 88, 537-558.

20. Wu, J.-L.; Hou, H.; Cheng, S.-Y. The dynamic impacts of financial institutions on economic growth: Evidence from the European Union. J. Macroecon. 2010, 32, 879-891. [CrossRef]

21. Barajas, A.; Chami, R.; Yousefi, S.R. The Finance and Growth Nexus Re-Examined: Do All Countries Benefit Equally? IMF Working Paper WP/13/130; International Monetary Fund: Washington, DC, USA, 2013.

22. Caviglia, G.; Krause, G.; Thimann, C. Key features of the financial sectors in EU accession countries. In Financial Sectors in EU Accession Countries; Thimman, C., Ed.; European Central Bank: Frankfurt, Germany, 2002.

23. Mehl, A.; Winkler, A. The Finance-Growth Nexus and Financial Sector Environment: New Evidence from Southeast Europe. Presented at the Ninth Dubrovnik Economic Conference on Banking and the Financial Sector in Transition and Emerging Market Economies, Dubrovnik, Croatia, 26-28 June 2003.

24. Berglof, E.; Bolton, P. The Great Divide and Beyond: Financial Architecture in Transition. J. Econ. Perspect. 2002, 16, 77-100. [CrossRef]

25. Koivu, T. Do Efficient Banking Sectors Accelerate Economic Growth in Transition Countries; BOFIT Discussion Paper No. 14; Bank of Finland: Helsinki, Finland, 2002.

26. Dawson, P.J. Financial development and growth in economies in transition. Appl. Econ. Lett. 2003, 10, 833-836. [CrossRef]

27. Fink, G.; Haiss, P.; Vuksic, G. Contribution of financial market segments at different stages of development: Transition, cohesion and mature economies compared. J. Financ. Stabil. 2008, 5, 431-455. [CrossRef]

28. Petkovski, M.; Kjosevski, J. Does banking sector development promote economic growth? An empirical analysis for selected countries in Central and South Eastern Europe. Econ. Res. Ekonom. Istraž. 2014, 27, 55-66. [CrossRef]

29. Caporale, G.M.; Rault, C.; Sova, A.D.; Sova, R. Financial Development and Economic Growth: Evidence from 10 New European Union Members. Int. J. Financ. Econ. 2015, 20, 48-60. [CrossRef]

30. Akimov, A.; Wijeweera, A.; Dollery, B. Financial development and economic growth: evidence from transition economies. Appl. Financ. Econ. 2009, 19, 999-1008. [CrossRef]

31. Yu, J.-S.; Hassan, M.K.; Sanchez, B. A re-examination of financial development, stock markets development and economic growth. Appl. Econ. 2012, 44, 3479-3489. [CrossRef]

32. Chortareas, G.; Magkonis, G.; Moschos, D.; Panagiotidis, T. Financial Development and Economic Activity in Advanced and Developing Open Economies: Evidence from Panel Cointegration. Rev. Dev. Econ. 2015, 19, 163-177. [CrossRef]

33. Hryckiewicz, A.; Kowalewski, O. Economic determinates, financial crisis and entry modes of foreign banks into emerging markets. Emerg. Mark. Rev. 2010, 11, 205-228. [CrossRef] 
34. Althammer, W.; Haselmann, R. Explaining foreign bank entrance in emerging markets. J. Comp. Econ. 2011, 39, 486-498. [CrossRef]

35. Cottarelli, C.; Dell'Ariccia, G.; Vladkova-Hollar, I. Early birds, late risers, and sleeping beauties: Bank credit growth to the private sector in Central and Eastern Europe and in the Balkans. J. Bank. Financ. 2005, 29, 83-104. [CrossRef]

36. De Haas, R.; van Lelyveld, I. Foreign banks and credit stability in Central and Eastern Europe. A panel data analysis. J. Bank. Financ. 2006, 30, 1927-1952. [CrossRef]

37. Cull, R.; Martínez Pería, M.S. Bank ownership and lending patterns during the 2008-2009 financial crisis: Evidence from Latin America and Eastern Europe. J. Bank. Financ. 2013, 37, 4861-4878. [CrossRef]

38. Allen, F.; Jackowicz, K.; Kowalewski, O.; Kozłowski, Ł. Bank lending, crises, and changing ownership structure in Central and Eastern European countries. J. Corp. Financ. 2015. [CrossRef]

39. Iwanicz-Drozdowska, M.; Witkowski, B. Credit growth in Central, Eastern, and South-Eastern Europe: The case of foreign bank subsidiaries. Int. Rev. Financ. Anal. 2016, 43, 146-158. [CrossRef]

40. Claessens, S.; Demirguc-Kunt, A.; Huizinga, H. How does Foreign Entry Affect Domestic Banking Markets? J. Bank. Financ. 2001, 25, 891-911. [CrossRef]

41. Bonin, J.P.; Hasan, I.; Wachtel, P. Bank performance, efficiency and ownership in transition countries. J. Bank. Financ. 2005, 29, 31-53. [CrossRef]

42. Lensink, R.; Meesters, A.; Naaborg, I. Bank efficiency and foreign ownership: Do good institutions matter? J. Bank. Financ. 2008, 32, 834-844. [CrossRef]

43. Havrylchyk, O.; Jurzyk, E. Inherited or earned? Performance of foreign banks in Central and Eastern Europe. J. Bank. Financ. 2011, 35, 1291-1302. [CrossRef]

44. Havrylchyk, O.; Jurzyk, E. Profitability of foreign banks in Central and Eastern Europe. Econ. Transit. 2011, 19, 443-472. [CrossRef]

45. Claeys, S.; Vander Vennet, R. Determinants of bank interest margins in Central and Eastern Europe: A comparison with the West. Econ. Syst. 2008, 32, 197-216. [CrossRef]

46. Efthyvoulou, G.; Yildirim, C. Market power in CEE banking sectors and the impact of the global financial crisis. J. Bank. Financ. 2014, 40, 11-27. [CrossRef]

47. Bruno, V.; Hauswald, R. The real effects of foreign banks. Rev. Financ. 2014, 18, 1683-1716. [CrossRef]

48. Aghion, P.; Howitt, P. Endogenous Growth Theory; MIT Press: Cambridge, MA, USA, 1998.

49. Mankiw, G.; Romer, D.; Weil, D.N. A Contribution to the Empirics of Economic Growth. Q. J. Econ. 1992, 107, 408-437. [CrossRef]

50. Barro, R.J.; Sala-i-Martin, X.I. Economic Growth; MIT Press: Boston, MA, USA, 2003.

51. Pereira, C.; Teles, V. Political Institutions and Substitute for Democracy: A Political Economy Analysis of Economic Growth; Mimeo: New York, NY, USA, 2009.

52. Przeworski, A.; Alvarez, M.; Cheibub, J.A.; Limongi, F. Democracy and Development: Political Institutions and Well-Being in the World, 1950-1990; Cambridge University Press: New York, NY, USA, 2000.

53. Iwanicz-Drozdowska, M.; Witkowski, B.; Smaga, P. Stability of Banking Sectors in CESEE Countries. Is Foreign Capital Like a Mother Hen? Mimeo: New York, NY, USA, 2016.

54. Claessens, S.; Lee, J. Foreign banks in low-income countries: recent developments and impacts. In Globalization and National Financial Systems; Hanson, J., Honohan, P., Majnoni, G., Eds.; World Bank: Washington, DC, USA, 2003; pp. 109-141.

55. Clarke, G.; Cull, R.; Martinez Peria, M.S.; Sanchez, S. Bank lending to small business in Latin America: Does bank origin matter? J. Money Credit Bank. 2005, 37, 83-118. [CrossRef]

56. Mian, A. Foreign, Private Domestic, and Government Banks: New Evidence from Emerging Markets; University of Chicago: Chicago, IL, USA, 2003.

57. Berger, A.; Clarke, G.; Cull, R.; Klapper, L.; Udell, G. Corporate Governance and Bank Performance: A Joint Analysis of the Static Selection and Dynamic Effects of Domestic, Foreign and State Ownership; World Bank Policy Research Working Paper No. 3632; World Bank: Washington, DC, USA, 2005.

58. Clarke, G.; Cull, R.; Martinez Peria, M.S.; Sanchez, S. Foreign Bank entry: experience, implications for developing countries and agenda for future research. World Bank Res. Obs. 2003, 18, 25-40. [CrossRef]

59. Claessens, S. Competitive implications of cross border banking. In Cross Border Banking: Regulatory Challenges; Caprio, G., Evanoff, D.D., Kaufman, G.G., Eds.; World Scientific Publishing: Hackensack, NJ, USA, 2006; pp. 151-182. 
60. Chopra, A. Opening up to Foreign Banks: Harnessing the Benefits and Avoiding the Pitfalls; Mimeo, International Monetary Fund: Washington, DC, USA, 2007.

61. Laeven, L.; Levine, R.; Michalopoulos, S. Financial innovation and endogenous growth. J. Financ. Intermed. 2015, 24, 1-24. [CrossRef]

62. Dell'Ariccia, G.; Marquez, R. Information and Bank Credit Allocation. J. Financ. Econ. 2004, 72, $185-214$. [CrossRef]

63. Sengupta, R. Foreign Entry and Bank Competition. J. Financ. Econ. 2007, 84, 502-528. [CrossRef]

64. Beck, T.; Martinez Peria, M.S. Foreign Bank Acquisitions and Outreach: Evidence from Mexico; World Bank Policy Research Working Paper No. 7823; World Bank: Washington, DC, USA, 2007.

65. Detragiache, E.; Gupta, P.; Tressel, T. Foreign Banks in Poor Countries: Theory and Evidence. J. Financ. 2008, 63, 2123-2160. [CrossRef]

66. Sorsa, P.; Bakker, B.; Duenwald, C.; Maechler, A.; Tiffin, A. Vulnerabilities in Emerging Southeastern Europe-How Much Cause for Concern? IMF Working Paper No. 07/236; IMF: Washington, DC, USA, 2007.

67. Peek, J.; Rosengren, E. The International Transmission of Financial Shocks: The Case of Japan. Am. Econ. Rev. 1997, 87, 495-505. [CrossRef]

68. Peek, J.; Rosengren, E. Collateral Damage: Effects of the Japanese Bank Crisis on the United States. Am. Econ. Rev. 2000, 90, 30-45. [CrossRef]

69. Acharya, V.; Schnabl, P. Do Global Banks Spread Global Imbalances? The Case of Asset-Backed Commercial Paper during the Financial Crisis of 2007-2009. IMF Econ. Rev. 2010, 58, 37-73. [CrossRef]

70. Popov, A.; Udell, G. Cross-Border Banking and the International Transmission of Financial Distress during the Crisis of 2007-2008; European Central Bank Working Paper No. 1203; ECB: Frankfurt, Germany, 2010.

71. Chava, S.; Purnandam, A. The effect of banking crisis on bank-dependent borrowers. J. Financ. Econ. 2011, 99, 116-135. [CrossRef]

72. Cetorelli, N.; Goldberg, L. Global Banks and International Shock Transmission: Evidence from the Crisis. IMF Econ. Rev. 2011, 59, 41-76. [CrossRef]

73. De Haas, R.; van Lelyveld, I. Multinational Banks and the Global Financial Crisis. Weathering the Perfect Storm? DNB Working Paper No. 322; De Nederlandsche Bank: Amsterdam, The Netherlands, 2011.

74. Blundell, R.; Bond, S. Initial Conditions and Moment Restrictions in Dynamic Panel Data Models. J. Econom. 1998, 87, 115-143. [CrossRef]

75. Arellano, M.; Bond, S. Some Tests of Specification for Panel Data: Monte Carlo Evidence and an Application to Employment Equations. Rev. Econ. Stud. 1991, 58, 277-297. [CrossRef]

76. De Gregorio, J. Economic Growth in Latin America. J. Dev. Econ. 1992, 39, 59-84. [CrossRef]

77. Borensztein, E.; De Gregorio, J.; Lee, J.W. How does foreign direct investment affect economic growth? J. Int. Econ. 1998, 45, 115-135. [CrossRef]

78. Bruno, M.; Easterly, W. Inflation crises and long-run growth. J. Monet. Econ. 1998, 41, 2-26. [CrossRef]

79. Khan, M.; Senhadji, A.S. Threshold effects in the relationship between inflation and growth. IMF Staff Pap. 2001, 48, 1-21.

80. Carlson, M.; King, T.; Lewis, K. Distress in the Financial Sector and Economic Activity; Working Papers Federal Reserve Board 43; Board of Governors of the Federal Reserve: Washington, DC, USA, 2009.

81. Carbó-Valverde, S.; Sánchez, L. Financial Stability and Economic Growth. In Crisis, Risk and Stability in Financial Markets; de Guevara Radoselovics, J.F., Monsálvez, J.M.P., Eds.; Palgrave Macmillan Studies in Banking and Financial Institutions, Palgrave MacMillan: Basingstoke, UK, 2013; pp. 8-23.

82. Creel, J.; Hubert, P.; Labondance, F. Financial stability and economic performance. Econ. Model. 2015, 48, 25-40. [CrossRef]

83. International Monetary Fund (IMF). Rethinking Financial Deepening: Stability and Growth in Emerging Markets; Staff Discussion Note, SDN 15/08; International Monetary Fund: Washington, DC, USA, 2015.

84. Carp, L. Can stock market development boost economic growth? Empirical evidence from emerging markets in Central and Eastern Europe. Procedia Econ. Financ. 2012, 3, 438-444. [CrossRef]

85. Beck, T.; Berrak, B.; Rioja, F.; Valev Neven, T. Who gets the credit? And does it matter? Households vs firms across countries. B.E. J. Macroecon. 2012, 12, 1-46. [CrossRef]

86. Sassi, S.; Gasmi, A. The effect of enterprise and household credit on economic growth: New evidence from European Union countries. J. Macroecon. 2014, 39, 226-231. [CrossRef]

87. Angeles, L. Credit Expansion and the Real Economy. Appl. Econ. Lett. 2015, 22, 1064-1072. [CrossRef] 
88. Leon, F. Enterprise Credit, Household Credit and Growth: New Evidence from 126 Countries; CREA Discussion Paper No. 17; University of Luxembourg: Luxembourg, 2016.

89. Rousseau, P.; Wachtel, P. What is Happening to the Impact of Financial Deepening on Economic Growth? Econ. Inq. 2011, 49, 276-288. [CrossRef]

90. Gardò, S.; Martin, R. The Impact of the Global Economic and Financial Crisis on Central, Eastern and South-Eastern Europe: A Stock-Taking Exercise; ECB Occasional Paper No. 114; European Central Bank: Frankfurt, Germany, 2010.

91. Jäger-Gyovai, K. Capital Market Development in CESEE and the Need for Further Reform. Financial Stability Report. 2014. Available online: http:/ / econpapers.repec.org/article/onboenbfs/y_3a2014_3ai_3a27_3ab_ 3a3.htm (accessed on 15 January 2017).

(C) 2017 by the authors. Licensee MDPI, Basel, Switzerland. This article is an open access article distributed under the terms and conditions of the Creative Commons Attribution (CC BY) license (http:/ / creativecommons.org/licenses/by/4.0/). 